\title{
The roles of protein kinases in learning and memory
}

\author{
Karl Peter Giese ${ }^{1}$ and Keiko Mizuno \\ Centre for the Cellular Basis of Behaviour, Institute of Psychiatry, King's College London, London SE5 9NU, United Kingdom
}

\begin{abstract}
In the adult mammalian brain, more than 250 protein kinases are expressed, but only a few of these kinases are currently known to enable learning and memory. Based on this information it appears that learning and memory-related kinases either impact on synaptic transmission by altering ion channel properties or ion channel density, or regulate gene expression and protein synthesis causing structural changes at existing synapses as well as synaptogenesis. Here, we review the roles of these kinases in short-term memory formation, memory consolidation, memory storage, retrieval, reconsolidation, and extinction. Specifically, we discuss the roles of calcium/calmodulin-dependent kinase II (CaMKII), the calcium/calmodulin kinase cascade, extracellular signal regulated kinase 1 and 2 (ERK1/2), cAMP-dependent protein kinase A (PKA), cGMP-dependent protein kinase G (PKG), the phosphatidylinositol 3-kinase (PI3K) pathway, and protein kinase $\mathrm{M} \zeta$ (PKM $\zeta$ ). Although these kinases are important for learning and memory processes, much remains to be learned as to how they act. Therefore, it will be important to identify and characterize the critical phosphorylation substrates so that a sophisticated understanding of learning and memory processes will be achieved. This will also allow for a systematic analysis of dysfunctional kinase activity in mental disorders.
\end{abstract}

Learning and memory are mediated by neuronal plasticity, which includes long-lasting strengthening of existing synapses (e.g., long-term potentiation [LTP]; for review, see Giese 2012), synaptogenesis (for review, see Stewart and Popov 2012), modulation of intrinsic excitability (for review, see Papoutsi et al. 2012), and adult neurogenesis (for review, see Stone and Frankland 2012). All of these plasticity processes may require protein kinases, enzymes that transfer phosphate groups to side chains of particular amino acids (serine/threonine or tyrosine) of target proteins. Phosphorylation at one or more sites is presumed to alter the conformation of target proteins impacting on the functioning or interaction with other proteins (Kim et al. 2011). This is a reversible process allowing for flexible signaling. Analysis of the Allen Mouse Brain Atlas suggests that at least 260 kinases are expressed in adult mouse brain. These kinases have different targets and they differ in their activation properties. A small subset of these kinases has been implicated in learning and memory. Here, we will review key data that have revealed the contribution of learning and memory kinases. Because of the vast literature, we will discuss mainly behavioral experiments that distinguish between distinct processes, such as memory formation and storage. From these studies it has emerged that learning and memory kinases regulate either (1) synaptic transmission by altering ion channel properties or densities, or (2) synaptic structure and synaptogenesis by impacting on protein synthesis.

\section{CaMKII}

Neuronal pathways to memory formation depend on activation of the NMDA receptor (e.g., Gruart et al. 2006; Whitlock et al. 2006), which leads to postsynaptic calcium entry (for review, see Lisman et al. 2012). A substantial fraction of incoming calcium binds to calmodulin which activates enzymes to modify the synapse. A major calcium/calmodulin target is calcium/calmodulin-dependent kinase II (CaMKII) (Fig. 1). Accordingly, CaMKII activity is increased during memory formation (e.g., Cammarota et al.

\section{${ }^{1}$ Corresponding author}

E-mail karl.giese@kcl.ac.uk

Article is online at http://www.learnmem.org/cgi/doi/10.1101/Im.028449.112.
1998) and blockade of CaMKII substantially impairs memory formation (for reviews, see Lisman et al. 2002; Elgersma et al. 2004; Irvine et al. 2006; Wayman et al. 2008; Lucchesi et al. 2011; Coultrap and Bayer 2012). This indicates that CaMKII has an essential function in memory formation. Although many studies have established this important role for CaMKII, it should be noted that some pharmacological experiments, such as studies with KN-62 and KN93, lack specificity (Wayman et al. 2008), and early mouse genetic studies also had their limitations. $\alpha$ CaMKII knockout (KO) mice were the first mutant mice generated to study mechanisms of learning and memory (Silva et al. 1992a,b), but these mutants have a milder phenotype than $\alpha$ CaMKII knockin (KI) mice with impaired calcium/calmodulin binding due to compensatory translocation of $\beta$ CaMKII into synapses (Elgersma et al. 2002). Furthermore, transgenic expression of a constitutively active form of $\alpha$ CaMKII leads to unwanted secondary changes in gene expression (Bejar et al. 2002).

$\alpha$ CaMKII and $\beta$ CaMKII are the two major CaMKII subunits/ isoforms in adult brain (for review, see Hanson and Schulman 1992). $\alpha$ CaMKII is expressed exclusively in glutamatergic neurons, and in the hippocampus it is not localized in the nucleus. Thus, $\alpha$ CaMKII is not directly involved in gene transcription in the hippocampus. Twelve CaMKII subunits assemble to form a homomeric or heteromeric holoenzyme. Despite being present in a heteromeric holoenzyme, $\alpha$ CaMKII and $\beta$ CaMKII have different roles in synaptic plasticity. A key feature of $\beta$ CaMKII is the binding to F-actin when calcium/calmodulin levels are at baseline (for review, see Coultrap and Bayer 2012). Binding of calcium/calmodulin to $\beta$ CaMKII dissociates the kinase from F-actin (Lin and Redmond 2008), allowing CaMKII to translocate to the postsynaptic density (Shen and Meyer 1999). F-actin binding is essential for hippocampus-dependent contextual fear memory formation and for targeting CaMKII holoenzymes to dendritic spines (Borgesius et al. 2011). In contrast, the kinase activity of $\beta C a M K I I$ is not required for contextual fear memory formation (Borgesius et al. 2011). Thus, $\beta$ CaMKII has a nonenzymatic role in memory formation. The transient release of $\beta$ CaMKII from F-actin may be important for reorganization of the cytoskeleton to enable remodeling of the dendritic spine (Okamoto et al. 2009), which appears necessary for late LTP and long-term memory (LTM) (e.g., Fukazawa et al. 2003). 


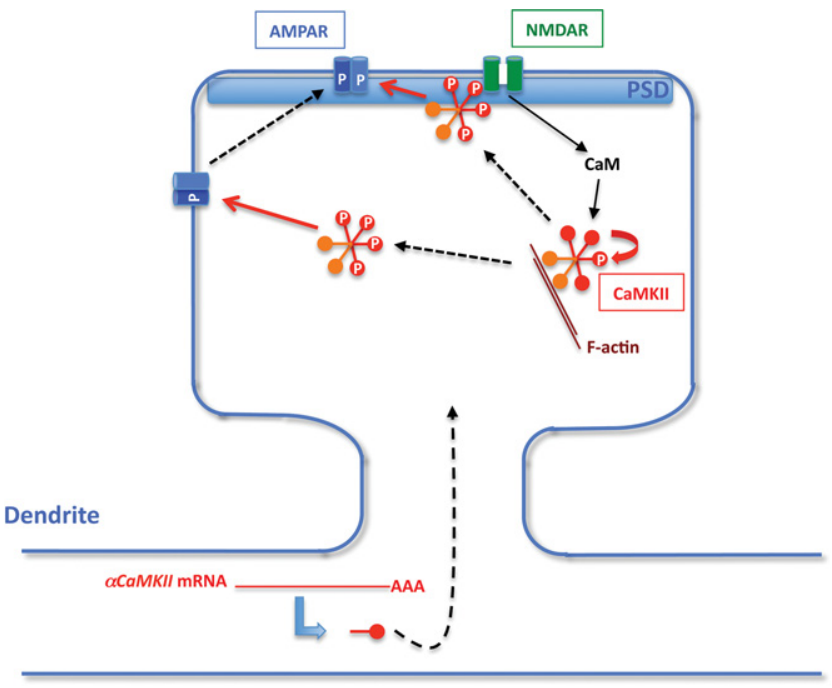

Figure 1. Model of the role of CaMKII in synaptic potentiation underlying memory formation. At the postsynapse NMDA receptor (NMDAR) activation leads to calcium influx. The incoming calcium binds to calmodulin $(\mathrm{CaM})$ resulting in the activation of CaMKII, consisting of $\alpha$ CaMKII (red) and $\beta$ CaMKII subunits (orange). Inactive CaMKII is bound to F-actin via binding of $\beta$ CaMKII subunits, whereas active CaMKII dissociates from F-actin. Activation of CaMKII also leads to an intersubunit autophosphorylation of $\alpha$ CaMKII at threonine-286 to prolong its kinase activity (phosphorylation is shown as a white " $\mathrm{P}$ "). Activated CaMKII phosphorylates the stargazin subunit of AMPA receptor (AMPAR) complexes enabling AMPARs to translocate to the postsynaptic density (PSD). This increases the number of AMPARs in the PSD causing an increase in synaptic transmission. Further, activated CaMKII translocates to the PSD and binds to the NMDAR via $\alpha$ CaMKII subunits, where CaMKII can phosphorylate GluA1 subunits of the AMPAR to enhance the conductivity of these receptors. Additionally, $\alpha$ CaMKII mRNA is locally translated in dendrites and newly synthesized $\alpha$ CaMKII is thought to translocate into the dendritic spine. This local translation is required for LTM, but not STM. Red arrows indicate phosphorylations and dashed arrows illustrate protein translocation. The model is a modification of the one presented in Lisman et al. 2012.

As well as binding F-actin, $\beta$ CaMKII unbound to calcium/calmodulin can also target the immediate-early gene Arc/Arg3.1 to inactive synapses where it promotes endocytosis of AMPA receptor subunits, which leads to synaptic depression (Okuno et al. 2012). It remains to be tested whether this Arc/Arg3.1 localization contributes to memory formation.

In contrast to $\beta$ CaMKII activity, $\alpha$ CaMKII activity is required for hippocampus-dependent memory formation. A KI mutation that blocks the catalytic activity of $\alpha$ CaMKII impairs memory formation in the inhibitory avoidance task (Yamagata et al. 2009). This deficit in memory formation can be partly overcome with repeated training (Yamagata et al. 2009). Consistent with this, a peptide derived from an endogenous CaMKII inhibitor, CaMKIIN, that specifically blocks CaMKII activity impairs contextual fear memory formation (Buard et al. 2010). An important aspect of $\alpha$ CaMKII activity is that the kinase autophosphorylates at threonine-286 (T286) (for review, see Irvine et al. 2006). T286 autophosphorylation is an intersubunit reaction within a holoenzyme. This autophosphorylation switches $\alpha$ CaMKII activity from calcium/calmodulin dependence to independence. Accordingly, it was suggested that $\alpha$ CaMKII acts a "memory molecule" at synapses, its persistent activity serving to preserve a memory of strong calcium signals (Lisman 1994). A KI mutation (T286A) that blocks T286 autophosphorylation causes severe impairments in hippocampus-dependent memory formation, indicating that this autophosphorylation is a critical process (Giese et al. 1998; Need and
Giese 2003; Irvine et al. 2005, 2011). For example, in contextual fear conditioning the T286A mutants are deficient in one-trial memory formation (Irvine et al. 2005, 2011). Interestingly, massed training overcomes this impairment, possibly due to generation of multi-innervated dendritic spines, a type of synapse where a spine receives more than one presynaptic input (Radwanska et al. 2011). The finding that memory can be stored in the absence of T286 autophosphorylation argues against an essential role for calcium/calmodulin-independent CaMKII activity in memory storage (Irvine et al. 2006). Consistent with this view, LTP induction is associated only with transient, but not persistent, increases in calcium/calmodulin-independent CaMKII activity (Lengyel et al. 2004; Lee et al. 2009; but see Fukunaga et al. 1993). Further, post-training block of CaMKII activity does not impair storage of contextual fear LTM (Buard et al. 2010). Taken together, the T286 autophosphorylation is a biochemical switch that prolongs synaptic signaling and enables one-trial memory formation, but may not contribute to memory storage. The role of T286 autophosphorylation is likely to strengthen existing synapses, as illustrated in Figure 1.

Besides the T286 autophosphorylation, $\alpha$ CaMKII can be phosphorylated at more sites, including T305 and T306, which prevents calcium/calmodulin activation of the kinase. Inactivation of T305/306 phosphorylation in KI mice does not impair contextual fear memory formation, but does block contextual discrimination (Elgersma et al. 2002). This indicates that the T305/ T306 phosphorylation is important for memory specificity. $\alpha$ CaMKII activity is also regulated by local translation of its dendritic mRNA. When the mRNA was confined to the soma by mutation of the $3^{\prime}$-untranslated region in mice, this regulation was shown to be important for cued and contextual fear LTM, but not short-term (STM) formation (Miller et al. 2002). $\alpha$ CaMKII is also implicated in adult hippocampal neurogenesis (Yamasaki et al. 2008), which may regulate reorganization of LTM after contextual fear conditioning (for review, see Inokuchi 2011). Accordingly, heterozygous $\alpha$ CaMKII KO mice have impaired hippocampal neurogenesis (Yamasaki et al. 2008) and deficient remote, but spared recent contextual fear LTM (Frankland et al. 2004). Moreover, $\alpha$ CaMKII has also been implicated in memory extinction. Heterozygous T286A mutants have impaired new learning induced by extinction training, whereas extinctionrelated unlearning is spared (Kimura et al. 2008a).

In future, it will be interesting to test whether the interaction between the NMDA receptor subunit GluN2B and $\alpha$ CaMKII contribute to memory storage, as this interaction appears to be required for LTP maintenance (Sanhueza et al. 2011). In agreement with this idea, point mutations in GluN2B that impair GluN2B/ CaMKII interaction cause a deficit in spatial memory retention, although LTP was not fully blocked and spatial learning was unaffected (Halt et al. 2012). For mechanisms of memory storage it is important that the signaling perpetuates beyond molecular turnover (Crick 1984; Lisman 1985). Recently, a model has been proposed as to how GluN2B/ $\alpha$ CaMKII signaling may persist by providing anchoring sites for AMPA receptors (Sanhueza and Lisman 2013). Another point of future investigations concerns the complex regulation of CaMKII activity. There are two endogenous CaMKII inhibitor proteins, which are regulated in their expression during contextual fear memory formation (Lepicard et al. 2006; Radwanska et al. 2010). The function of this negative feedback awaits investigation. Moreover, CaMKII has been implicated in synaptic tagging based on experiments with unspecific inhibitors (Redondo et al. 2010). More specific inhibitors will be required to ensure that CaMKII is required for synaptic tagging or a behavioral counterpart, whereby rodents are exposed to two consecutive tasks, and hippocampal LTM formation in the second task is enabled by exposure to an open field $1 \mathrm{~h}$ before (Moncada 
and Viola 2007). Finally, there appears to be a link between CaMKII dysregulation and memory impairment in diseases that requires more studying. So far, polymorphisms in the $\alpha$ CaMKII gene associate with working memory abilities in humans (Easton et al. 2012). Additionally, in a mouse model of Angelman syndrome restoration of $\alpha$ CaMKII dysregulated by increased phosphorylation at T305/T306 rescues hippocampal learning impairments (van Woerden et al. 2007), and $\alpha$ CaMKII dysfunction might cause learning deficits in Alzheimer's disease (Zeng et al. 2010; Reese et al. 2011).

\section{CaM kinase cascade}

NMDA receptor activation at the synapse not only induces CaMKII, it also activates the CaM kinase cascade that is involved in LTM formation (Fig. 2). This kinase cascade activates gene transcription dependent on the cAMP-responsive element binding protein (CREB), which is essential for LTM (Bito et al. 1996; Bartsch et al. 1998; Silva et al. 1998; Kang et al. 2001; Wei et al. 2002; Peters et al. 2003; Blaeser et al. 2006; Mizuno et al. 2007; Fukushima et al. 2008; Liu et al. 2008). Interestingly, in vitro CREB activation by the CaM kinase cascade is more rapid than CREB activation by extracellular signal-regulated kinases (ERKs) (Wu et al. 2001). The CaM kinase cascade consists of CaM kinase kinases (CaMKKs) that activate CaMKI and CaMKIV (Wayman et al. 2008). In brain there are two CaMKK isoforms, CaMKK $\alpha$, and CaMKK $\beta$, four CaMKI isoforms, CaMKI $\alpha, \mathrm{CaMKI} \beta, \mathrm{CaMKI} \gamma$, and CaMKIS, and two CaMKIV splice variants. A key feature of the CaM kinase cascade is that the activation of CaMKI/ CaMKIV by CaMKK requires that both kinases bind to calcium/ calmodulin. Thus, signaling by the CaM kinase cascade requires a calcium signal that persists long enough that two calcium/ calmodulin-bound kinases encounter each other. This could lead to a proofreading effect (only "real" signals are transmitted) (Swulius and Waxham 2008).

The first studies of the role of the CaM kinase cascade in learning and memory focused on CaMKIV function. Analysis of
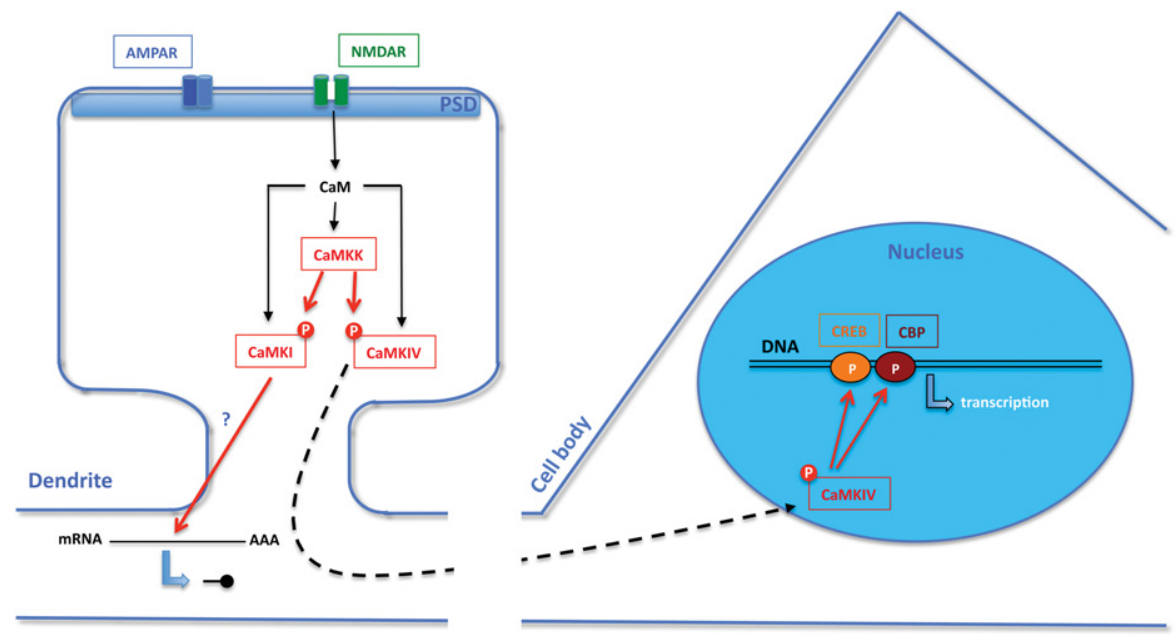

Figure 2. Model of the role of the CaM kinase cascade in memory consolidation. At the postsynapse NMDAR activation leads to calcium influx. The incoming calcium binds to calmodulin resulting in the activation of CaMKK. CaMKK activates CaMKI and CaMKIV, when these kinases have bound CaM. Active CaMKI may induce local translation of dendritic mRNA. Active CaMKIV phosphorylates CREB and CREB-binding protein (CBP) in the nucleus to induce gene transcription, which ultimately results in protein synthesis. The newly synthesized proteins are targeted to the activated synapses; they are essential for memory consolidation. Red arrows indicate phosphorylations and dashed arrows illustrate translocation of the protein. different mutant mouse lines concluded that CaMKIV is not important for spatial learning and memory but it is required for contextual fear LTM formation (Ho et al. 2000; Kang et al. 2001; Wei et al. 2002; Takao et al. 2010). Furthermore, CaMKIV expression in the hippocampus declines with aging and CaMKIV overexpression restores age-related impairments in contextual fear LTM formation (Fukushima et al. 2008).

Studies on the roles of the CaMKKs confirm that the CaM kinase cascade is important for LTM formation. CaMKK $\beta$ KO mice have impaired CREB activation during spatial memory formation and deficits in LTM, but not STM, after training in the social transmission of food preferences task (Peters et al. 2003). CaMKK $\alpha$ KO mice have deficits in contextual fear LTM as well as conditioninginduced CaMKIV activation, CREB phosphorylation, and transcription of the brain-derived neurotrophic factor (BDNF) gene (Blaeser et al. 2006; Mizuno et al. 2006). Furthermore, pharmacological inhibition of $\mathrm{CaMKK} \alpha / \beta$ impairs CaMKI $\alpha$ activation as well as object recognition LTM (Tinsley et al. 2012). Block of $\mathrm{CaMKK} \alpha / \beta$ also impairs synthesis of plasticity-related proteins after strong LTP induction that is thought to contribute to LTM formation (Redondo et al. 2010). Other in vitro studies, which include inhibition of $\mathrm{CaMKK} \alpha / \beta$, have suggested that there is crosstalk between the CaM kinase cascade and ERK (Schmitt et al. 2005) or Akt signaling (Fortin et al. 2012), and that the kinase cascade regulates local protein synthesis via CaMKI activation (Fortin et al. 2012; Srivastava et al. 2012). However, it remains unknown whether these mechanisms are relevant for memory formation in the intact brain.

Interestingly, the roles of CaMKK $\alpha$ and CaMKK $\beta$ in LTM formation are sex specific. Only male, but not female, CaMKK $\beta$ KO mice are impaired in CREB activation and LTM formation (Mizuno et al. 2007). Further, there are CaMKK $\beta$-dependent gene transcriptions that are activated after contextual fear conditioning only in male but not in female wild-type mice (AntunesMartins et al. 2007; Mizuno et al. 2007). Moreover, male, but not female, CaMKK $\alpha$ KO mice are impaired in contextual LTM formation (Mizuno et al. 2006). CaMKK $\alpha$ regulates BDNF expression in a male-specific manner after contextual fear conditioning (Mizuno et al. 2006; also see Mizuno et al. 2012). Taken together, these findings suggest that memory consolidation differs between males and females (Mizuno and Giese 2010). Since most mechanistic studies of LTM formation have used only males, more studies with females are needed to more fully understand the mechanistic differences between males and females.

\section{MAPK family}

The mitogen-activated protein kinase (MAPK) family has also been implicated in learning and memory (Fig. 3). This family consists of seven kinases: ERK 1 , 2, and 5, c-Jun N-terminal kinases (JNKs) $1-3$, and p38 (for review, see Sherrin et al. 2011). These MAPKs are part of a three-kinase signaling cascade where a MAPK kinase kinase (MKKK) activates a MAPK kinase (MKK) that in turn activates a MAPK. Such in-series kinase cascades are thought to cause very high signal amplification, leading to all-ornone signaling (Adams and Sweatt 

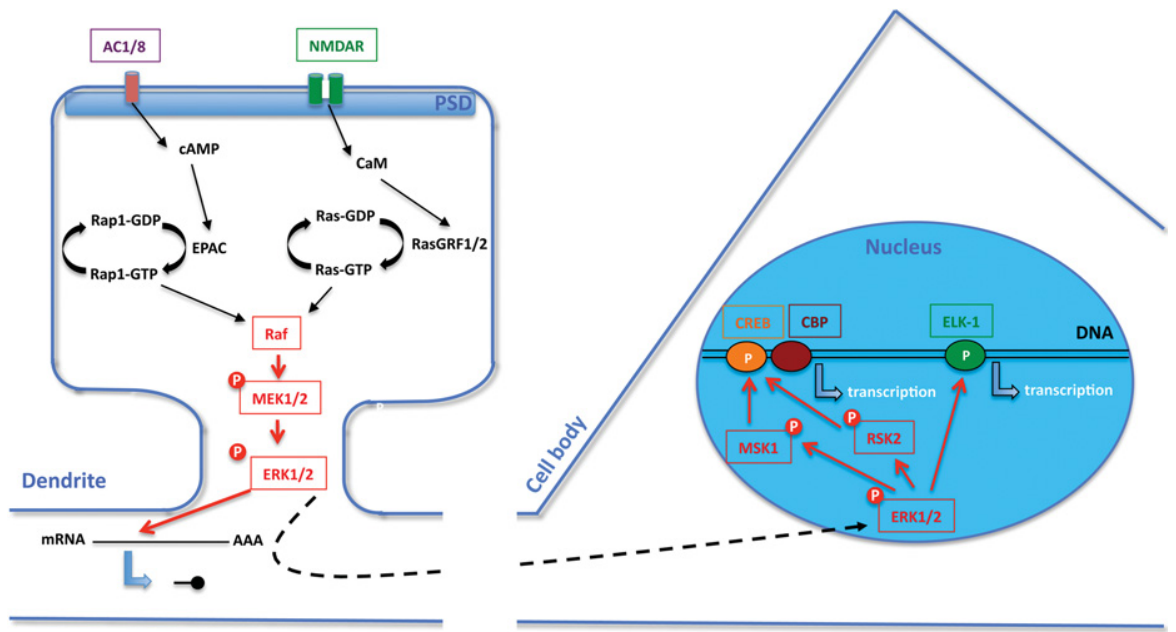

Figure 3. Model of the role of ERK $1 / 2$ signaling in memory consolidation. At the postsynapse NMDAR activation leads to calcium influx. There are two routes to activate the MAPK cascade. First, incoming calcium binds to calmodulin resulting in the activation of adenylate cyclase 1 and 8 leading to activation of the exchange protein activated by CAMP-(EPAC) that activates the small GTPase Rap1 (GTP-bound form is active) (Yang et al. 2012), which binds to, and thereby activates, Raf kinase inducing the MAPK cascade. Second, CaM induces the Ras nucleotide exchange factors RasGRF1 and 2 leading to Ras activation (GTP bound), which binds to, and thereby activates, Raf kinase inducing the MAPK cascade. Activated ERK $1 / 2$ regulate local translation of dendritic mRNA. They also contribute to the induction of transcription of plasticity-related genes by activation of the transcription factors CREB and ELK-1. The newly synthesized proteins are targeted to the activated synapses; they are essential for memory consolidation. Red arrows indicate phosphorylations and dashed arrows illustrate translocation of the protein.

2002). Signaling that involves ERK1/2 is essential for activation of transcription during LTM formation, whereas the other MAPK cascades, including ERK5, p38, or JNKs, have different roles in learning and memory.

Pharmacological and mouse molecular genetic studies have shown that ERK1/2 are required for LTM but not STM (Adams and Sweatt 2002; Davis and Laroche 2006; Giovannini 2006; Philips et al. 2007; Adaikkan and Rosenblum 2012). For example, post-training administration of a blocker of MEK1/2, the upstream kinases of ERK1/2, impairs fear LTM formation (Atkins et al. 1998). Further, forebrain-restricted expression of a dominant-negative form of MEK1 impairs contextual fear LTM, but spares STM (Kelleher et al. 2004; Shalin et al. 2004). Since ERK1/ 2 are required for LTM formation, their activation after training has been studied in detail. For example, contextual fear conditioning induces ERK2 activation in the hippocampus $1 \mathrm{~h}$ after training and this activation is (1) specific for the context-shock association, (2) transient as it returns to baseline within $24 \mathrm{~h}$ after training, and (3) dependent on NMDA receptor function (Atkins et al. 1998). ERK1/2 are also transiently activated in other brain areas after training in different memory tasks (Adams and Sweatt 2002; Davis and Laroche 2006; Giovannini 2006; Adaikkan and Rosenblum 2012). All but one ERK1/2 activation studies used only male rodents so that it remains unknown whether similar regulations occur in females. Indeed, sex differences are likely as ERK1/2 activation in the hippocampus occurs only in males and not in females after background contextual fear conditioning (Gresack et al. 2009). This finding is consistent with male-specific transcriptions occurring during consolidation of contextual fear memory (Mizuno et al. 2006, 2007; Antunes-Martins et al. 2007).

During LTM formation the prime function of ERK1/2 appears to be the activation of transcription dependent on CREB. For example, contextual fear conditioning activates ERK1/2 and mitogen- and stress-activated protein kinase 1 (MSK1) in the same hippocampal neurons (Sindreu et al. 2007). MSK1 phosphorylates the transcription factor CREB after its activation by ERK $1 / 2$, and CREB induction is essential for memory consolidation (Silva et al. 1998; Chwang et al. 2007). This ERK1/2-MSK1 pathway has been suggested as the major route for CREB activation in the hippocampus (Xia and Storm 2012), although MSK1 kinase-dead KI mice appear to have normal hippocampal memory formation (B.G. Frenguelli, pers. comm.)

Activation of the ERK cascade requires Ras GTPases, of which there are different isoforms in neurons, or Rap1 GTPase (Fig. 3). In the case of Ras activation of the ERK cascade, the calcium/ calmodulin-sensitive guanine nucleotide exchange factors Ras-GRF1 and RasGRF2 are important (Feig 2011). The ERK1/2-MSK1 pathway requires cAMP production by calcium/calmodulin-dependent adenylate cyclases (Sindreu et al. 2007; Xia and Storm 2012; also see Ahi et al. 2004). ERK1/2 activation by cAMP involves Rap1 and is independent of PKA (Morozov et al. 2003; Obara et al. 2007; Ravni et al. 2008). In addition to MSK1, ERK1/2 also activate ribosomal S6 protein kinase 2 (RSK2), which is mutated in Coffin-Lowry syndrome, a form of X-linked mental retardation (Schneider et al. 2011). Furthermore, ERK1/2 can activate the transcription factor Elk-1 which regulates the expression of immediateearly genes such as Nr4a1 (Davis and Laroche 2006; Besnard et al. 2011).

As well as inducing gene transcription during memory consolidation, ERK1/2 might also regulate local dendritic protein synthesis (Kelleher et al. 2004). In addition to these signaling roles in excitatory neurons, ERK1/2 signaling can also regulate GABA release from inhibitory neurons (Cui et al. 2008). The ERK1/2 activity in inhibitory neurons is regulated by neurofibromin, a Ras GTPase activating protein (mutated in neurofibromatosis type 1 ), and overactivation of ERK1/2 leads to enhanced GABA release as well as impaired LTP induction (Costa et al. 2002; Cui et al. 2008).

ERK1/2 are also important for retrieval-induced processes. Retrieval of LTM, which induces memory destabilization and reconsolidation, leads to ERK1/2 activation (Kelly et al. 2003). Pharmacological inhibition of MEK1/2 at the time of retrieval leads to erasure of LTM (Kelly et al. 2003; Duvarci et al. 2005; Cestari et al. 2006; Valjent et al. 2006; Languille et al. 2009), indicating that ERK1/2 signaling contributes to reconsolidation, which requires gene transcription and protein synthesis (Nader and Hardt 2009). Moreover, ERK1/2 signaling has also been implicated in fear memory extinction. Pharmacological inhibition of MEK1/2 impairs extinction (Lu et al. 2001; Cammarota et al. 2005; Herry et al. 2006; Fischer et al. 2007). Extinction training of fear LTM induces ERK1/2 phosphorylation in the amygdala and hippocampus (Herry et al. 2006; Fischer et al. 2007). The time course of ERK1/2 phosphorylation indicates that ERK1/2 are transient, and are in part nuclear in hippocampal CA1 neurons (Fischer et al. 2007; Tronson et al. 2009). Such a pattern of activation is consistent with a putative role for ERK1/ 2 activation in activation of transcription underlying consolidation of extinction memory. Finally, pharmacological inhibition of ERK1/2 also impairs contextual fear memory retrieval (Chen et al. 2005). 
In comparison with ERK1/2, much less is known about the roles of the other MAPK family members in learning and memory. In adult brain ERK5 is expressed only in neuronal progenitor cells. Accordingly, inducible ERK5 KO mice have attenuated hippocampal neurogenesis and learning and memory impairments that include deficits in remote LTM after training in an inhibitory avoidance task (Pan et al. 2012). Further, the role of p38 in learning and memory has been best characterized after training in an inhibitory avoidance task. p38 activation occurs immediately after training in this task and the activation declines within 30 min (Alonso et al. 2003). Pharmacological inhibition of p38 immediately after training impairs both STM and LTM formation (Alonso et al. 2003). Additionally, pharmacological block of p38 in hippocampal area CA1 impairs extinction of inhibitory avoidance memory (Rossato et al. 2006). p38 activation by Ras-GRF1 has been implicated in the induction of long-term depression (LTD) (for review, see Feig 2011). Finally, JNKs also become activated during hippocampal memory formation. Contextual fear conditioning induces the activation $1 \mathrm{~h}$ after, but not $30 \mathrm{~min}$ after, conditioning and JNK activity returns to baseline within $8 \mathrm{~h}$ (Sherrin et al. 2010). Pharmacological inhibition of the JNKs immediately after conditioning enhances contextual fear mediumterm memory (MTM) but not STM (Sherrin et al. 2010; see also Bevilaqua et al. 2003). Consistent with this, psychological stress effects that impair contextual fear LTM formation are mediated by JNK2 and JNK3 (Sherrin et al. 2010). Thus, JNK activation negatively regulates LTM formation. Moreover, JNKs appear to promote memory extinction (Bevilaqua et al. 2007). The roles of the JNKs in learning and memory may be explained by their involvement in LTD (Sherrin et al. 2011).

\section{PKA}

Invertebrate studies point to an important role for cAMP signaling and cAMP-dependent protein kinase A (PKA) for memory formation (for reviews, see Dudai 1988; Kandel 2012). For example, in Aplysia PKA signaling has been implicated both in STM and LTM formation. PKA is a tetrameric holoenzyme that consists of two catalytic and two regulatory subunits. In the basal state the regulatory subunits inhibit the catalytic subunits. However, upon binding of cAMP the regulatory subunits dissociate from the catalytic subunits enabling phosphorylation of substrates. In mammals there are four genes encoding regulatory subunits $(\mathrm{RI} \alpha, \mathrm{RI} \beta, \mathrm{RII} \alpha, \mathrm{RII} \beta)$ and three genes encoding catalytic subunits $(\mathrm{C} \alpha, \mathrm{C} \beta, \mathrm{C} \gamma)$ (Abel and Nguyen 2008). Mouse KO studies of PKA isoforms have indicated that PKA plays a role in mammalian learning and memory, but the phenotypes are difficult to interpret due to compensations by other PKA isoforms (Brandon et al. 1997). However, conditional transgenic overexpression of the dominant negative regulatory subunit $\mathrm{R}(\mathrm{AB})$ revealed that PKA signaling is required for LTM, but not STM, after contextual fear conditioning (Abel et al. 1997; Isiegas et al. 2006). Pharmacological studies have confirmed a role for PKA signaling in LTM formation (Bernabeu et al. 1997; Barad et al. 1998; Bourtchouladze et al. 1998, Ahi et al. 2004; Quevedo et al. 2004). After conditioning there are two waves of
PKA activity (Bernabeu et al. 1997; Bourtchouladze et al. 1998). The first PKA wave occurs immediately after training and the second after 3-6 h. Both waves of PKA activity might be important to induce CREB-mediated gene transcription (Ahi et al. 2004; Sindreu et al. 2007). Next to regulating gene transcription for LTM formation, PKA has also been implicated in synaptic tagging (Young et al. 2006; Moncada et al. 2011) and long-term reduction of the slow afterhyperpolarization (AHP), which regulates neuronal firing (Oh et al. 2009). Further, PKA activity is required for the behavioral counterpart of synaptic tagging (Moncada et al. 2011). Finally, as well as LTM formation in mammals, PKA signaling has also been suggested to contribute to the inhibition of extinction (Ahi et al. 2004; Quevedo et al. 2004; Isiegas et al. 2006).

\section{PKG}

cGMP-dependent protein kinase (PKG) is activated by cGMP that is produced by soluble guanylate cyclase after stimulation by nitric oxide (NO). NO synthase is closely coupled to activation of the NMDA receptor. There are two PKG isoforms encoded by different genes. Neuronal KO of isoform I (cGKI) results in specific impairment in cued fear LTM formation (Paul et al. 2008). These cGKI KO mice are not deficient in cued fear STM and contextual fear LTM. This suggests that PKG signaling in the amygdala is required for LTM formation. Consistent results have been obtained with pharmacological inhibition in the amygdala, although there is concern about the specificity of PKG blockers (Valtcheva et al. 2009). Post-training injection of the most specific PKG inhibitor into the lateral amygdala impairs cued fear LTM (Ota et al. 2008). Further, PKG inhibition impairs ERK activation and ERKdriven gene expression in the lateral amygdala and the auditory thalamus (Ota et al. 2010). The latter has been interpreted as evidence for retrograde signaling at synapses.

\section{PI3K}

The phosphatidylinositol 3-kinase (PI3K) pathway has also been implicated in learning and memory (Fig. 4). PI3K phosphorylates
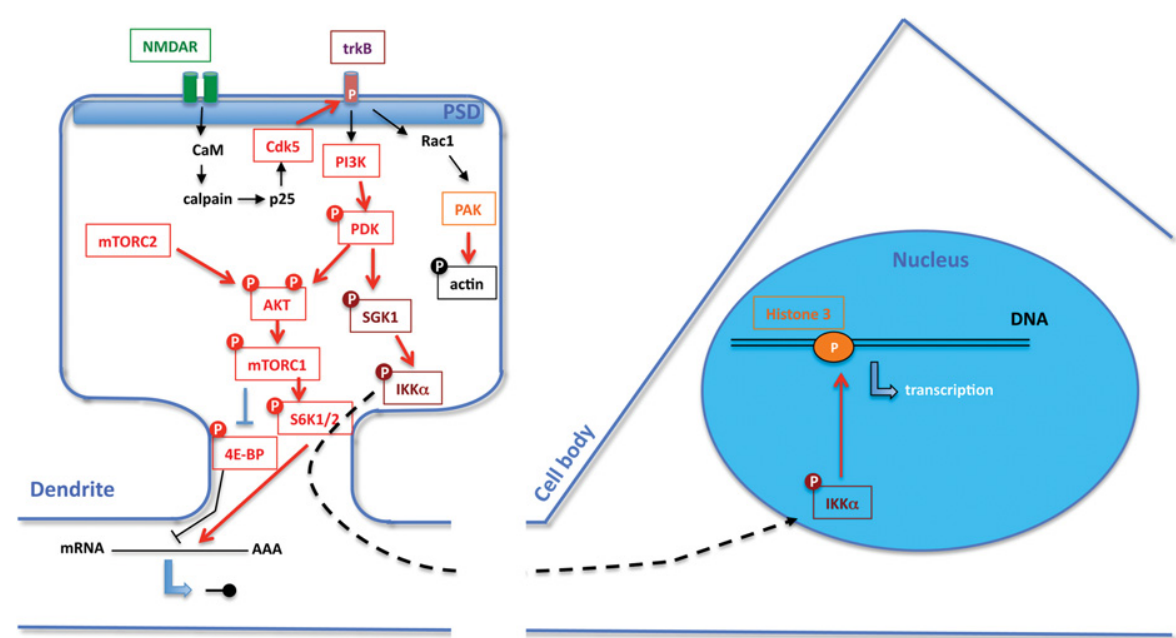

Figure 4. Model of the role of $\mathrm{PI} 3 \mathrm{~K}$ signaling in memory consolidation. At the postsynapse BDNF activates the trkB receptor, resulting in the activation of PI3K. PI3K activates PDK, which in turn activates mTORC1 to regulate local translation of dendritic mRNA. PDK also activates SGK1 to activate IKK $\alpha$, which phosphorylates histone 3 in the nucleus to facilitate gene transcription that contributes to memory consolidation. Additionally, NMDA receptor activation leads to p25 formation by calpainmediated cleavage of $\mathrm{p} 35$. Cdk5 phosphorylates trkB and this phosphorylation is essential for Rac1 and PAK activation to induce actin remodeling. Red arrows indicate phosphorylations and dashed arrows illustrate translocation of the protein. 
phosphatidylinositols, which activate 3-phosphoinositide-dependent kinase (PDK) and Akt (also called protein kinase B) (Pal and Mandal 2012). PI3K is regulated by receptor tyrosine kinases including trkB, the BDNF receptor. Fear conditioning increases BDNF protein expression and trkB activation in the amygdala (Ou and Gean 2006). Pharmacological studies indicated that this BDNF signaling route induces PI3K/Akt signaling, which is essential for fear LTM formation (Lin et al. 2001; Ou and Gean 2006). Additionally, trkB KI mutants with blocked activation of PI3K/Akt signaling have impaired cued fear LTM formation, while contextual fear LTM is spared (Musumeci et al. 2009). Further, hippocampal PI3K/Akt signaling is not known to have a role in spatial memory formation (Dash et al. 2002; Horwood et al. 2006; Chao et al. 2007). Thus, in the amygdala PI3K/Akt signaling is important for LTM formation, while this pathway may not be required for hippocampal LTM formation. However, in the hippocampus PI3K/Akt signaling is essential for retrieval of contextual fear LTM (Chen et al. 2005; also see Barros et al. 2001). Retrieval of contextual fear LTM leads to activation of PI3K/Akt signaling in the hippocampus, which induces ERK activation. Pharmacological block of PI3K and ERK impairs retrieval of contextual fear LTM, even $12 \mathrm{~d}$ after conditioning. Additionally, hippocampal PI3K/Akt signaling is required for extinction but not reconsolidation of contextual fear LTM (Chen et al. 2005).

The mammalian target of rapamycin (mTOR) is a kinase regulated by Akt phosphorylation (for review, see Hoeffer and Klann 2010). mTOR exists in two complexes, mTORC1 and mTORC2. In adult brain mTORC1 regulates protein synthesis by activating p70 S6 kinase 1 and 2 (S6K1/2) and other unknown factors (Stoica et al. 2011). Studies with the inhibitor rapamycin have established that mTORC1 is required for consolidation and reconsolidation of aversive LTM (Parsons et al. 2006; Bekinschtein et al. 2007; Stoica et al. 2011; Jobim et al. 2012). This is in agreement with an up-regulation of $\mathrm{S} 6 \mathrm{~K} 1 / 2$ phosphorylation $\sim 30-60 \mathrm{~min}$ after training (Parsons et al. 2006; Bekinschtein et al. 2007). Mouse genetic studies support the pharmacological studies in part. Brain-specific KO of FKBP12 increases mTOR activity and enhances contextual fear LTM but not STM (Hoeffer et al. 2008; but compare with Ehninger et al. 2008). Furthermore, S6K1 and S6K2 KO mice have impaired contextual LTM formation (Antion et al. 2008). Finally, enhanced mTORC1 signaling may contribute to memory deficits associated with autism spectrum disorder (for review, see Ehninger and Silva 2011). For example, a mouse model of tuberous sclerosis has enhanced mTORC1 signaling and impaired contextual discrimination and spatial reversal learning. These learning and memory deficits can be restored by rapamycin treatment that adjusts mTORC1 activity. In contrast with mTORC1, mTORC2 does not regulate protein synthesis during memory formation (Huang et al. 2013). Instead, mTORC2 phosphorylates Akt at serine 473 and controls actin polymerization at synapses, which is required for consolidation of fear LTM (Huang et al. 2013).

Another important PI3K/Akt target is glycogen synthase kinase $3 \beta$ (GSK-3 $\beta$ ) (for review, see Giese 2009). Akt phosphorylation at serine-9 (S9) inhibits GSK-3 $\beta$ activity. Inhibition of GSK-3 $\beta$ during LTP has been hypothesized to prevent early subsequent LTD (Peineau et al. 2007). Accordingly, LTP induction is associated with inhibition of GSK-3 $\beta$ (Hooper et al. 2007). Inhibitory $S 9$ phosphorylation of GSK-3 $\beta$ increases in hippocampus and amygdala during fear LTM formation (Fujio et al. 2007; Maguschak et al. 2008). This suggests that GSK-3 $\beta$ constrains memory formation. Consistently, pharmacological inhibition of GSK-3 $\beta$ enhances fear LTM formation, whereas transgenic overexpression of GSK-3 $\beta$ impairs spatial memory formation (Hernandez et al. 2002). Additionally, GSK-3 $\beta$ has also been implicated in reconsolidation (Kimura et al. 2008b; Wu et al. 2011) and memory retrieval (Hong et al. 2012).

As well as Akt, serum- and glucorticoid kinase 1 (SGK1) is a downstream target of PI3K signaling (Park et al. 1999). PDK1 phosphorylates SGK1 at threonine-256, which is required in hippocampal area CA1 for spatial memory formation (Lee et al. 2006). Further, SGK1 is phosphorylated at serine-78 by ERK (Lee et al. 2006). This phosphorylation is not important for spatial memory formation but it is required for contextual fear LTM formation (Lee et al. 2007). Interestingly, SGK1 expression levels are also up-regulated after contextual fear conditioning and after reactivation of contextual LTM (von Hertzen and Giese 2005). SGK1 activates IкB kinase $\alpha$ (Tai et al. 2009), which contributes to reconsolidation of contextual fear LTM and associated histone H3 modification, impacting on gene transcription (Lubin and Sweatt 2007).

\section{Cdk5}

Cyclin-dependent kinase 5 (Cdk5) is not involved in cell division despite its name, but it has a function in synaptic plasticity in post-mitotic neurons (for review, see Angelo et al. 2006). The main route of Cdk5 activation is by binding to the regulatory subunit p35. The calcium-dependent protease calpain can cleave p35 into p25, a smaller protein that also activates Cdk5 (Fig. 4). In comparison with p35, p25 has a longer half-life and is not membrane bound (Patrick et al. 1999). Thus, p25 generation enhances Cdk5 activity and changes its subcellular location. Recently, it was shown that p25 is generated in the hippocampus during spatial memory formation (Engmann et al. 2011a). This suggests that p25 generation is a memory mechanism, which is confirmed by the following experiments. Overexpression of p25 at physiological levels enhances spatial and contextual memory formation (Angelo et al. 2003; Fischer et al. 2005; Ris et al. 2005). Heterozygous p35 KO mice have impaired spatial reversal learning (Engmann et al. 2011b). These effects are notable in female but not in male mice (Ris et al. 2005; Engmann et al. 2011b). Mice with pharmacological inhibition of Cdk5 and region-restricted Cdk5 KO mice have impaired contextual fear and spatial memory formation (Fischer et al. 2002, 2003; Guan et al. 2011; but see Hawasli et al. 2007). Taken together, these findings suggest that p25/Cdk5 contributes to hippocampal memory formation. Cdk5 phosphorylates the BDNF receptor trkB at serine 478 . This phosphorylation is essential for spatial memory formation and BDNF-induced structural plasticity (Lai et al. 2012). Interestingly, the p25/Cdk5 signaling route may be impaired in Alzheimer's disease, due to reduced p25 expression in early and severe stages (Taniguchi et al. 2001; Yoo and Lubec 2001; Tandon et al. 2003; Engmann et al. 2011a). p25/Cdk5 enhances synaptogenesis (Fischer et al. 2005; Engmann et al. 2011a), possibly acting in the nucleus (Lai and Ip 2009; Engmann et al. 2011b). Cdk5 has also been implicated in the regulation of extinction (Sananbenesi et al. 2007). In this case, Cdk5 activity slows the rate of extinction.

\section{PKC including PKM $\zeta$}

The protein kinase C (PKC) family includes 12 isoenzymes (Jaken 1996). The conventional PKCs $(\alpha, \beta$ I and $\beta I I, \gamma)$ require calcium and diacylglycerol (DAG) for their activation, whereas the novel PKCs $(\delta, \epsilon, \eta, \theta)$ require only DAG. The so-called atypical PKCs $(\zeta, \iota, \lambda)$ do not require DAG for their activation. PKC $\gamma$ KO mice have a very subtle impairment in contextual fear memory formation (Abeliovich et al. 1993), while PKC $\beta$ KO mice have substantially impaired cued and contextual fear memory formation, even after intensive training (Weeber et al. 2000). Furthermore, 
pharmacological block of the conventional PKCs in hippocampal area CA1 impairs acquisition, consolidation, and reconsolidation of spatial memory (Bonini et al. 2007).

PKM $\zeta$, a brain-specific form of PKC $\zeta$ (Hernandez et al. 2003), has evoked a lot of interest due to a suggested critical function in memory storage (Fig. 5; for review, see Sacktor 2011). PKM $\zeta$ lacks a regulatory domain making the kinase constitutively active. An alternate promoter leads to synthesis of $P K M \zeta$ mRNA, which is transported into dendrites where it is locally translated. Under basal conditions local translation of PKM $\zeta$ mRNA is inhibited by PIN1, but synaptic activity relieves this inhibition (Westmark et al. 2010). Once PKM $\zeta$ is synthesized, it promotes its own translation by blocking PIN1. Continued PKM $\zeta$ synthesis is thought to occur only at activated synapses, where the kinase would promote GluA2 trafficking to maintain enhanced synaptic transmission (Migues et al. 2010).

Studies with an inhibitory peptide, called $\zeta$ inhibitory peptide (ZIP), suggested that $\mathrm{PKM} \zeta$ is required for memory storage. First, it was shown that injection of ZIP into the hippocampus erases a consolidated spatial LTM (Pastalkova et al. 2006). Further, ZIP injection into the basolateral amygdala blocks cued and contextual fear LTM as well as inhibitory avoidance LTM (Serrano et al. 2008; Kwapis et al. 2009). However, not all memory storage processes are ZIP-dependent (for review, see Glanzman 2013). For example, injection of ZIP into the dorsal hippocampus does not affect contextual fear LTM, although this part of the hippocampus is required for contextual LTM (Serrano et al. 2008; Kwapis et al. 2009). A recent study has claimed that ZIP does not block specifically PKM $\zeta$ (Wu-Zhang et al. 2012). However, the design of this study has been criticized and more evidence for ZIP specificity has been provided (Yao et al. 2012). Nonetheless, it is clear that ZIP affects targets in addition to PKM $\zeta$ (Lee et al. 2013; Volk et al. 2013). This was clearly demonstrated with

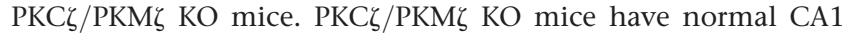
LTP in hippocampal slices and its maintenance is blocked by

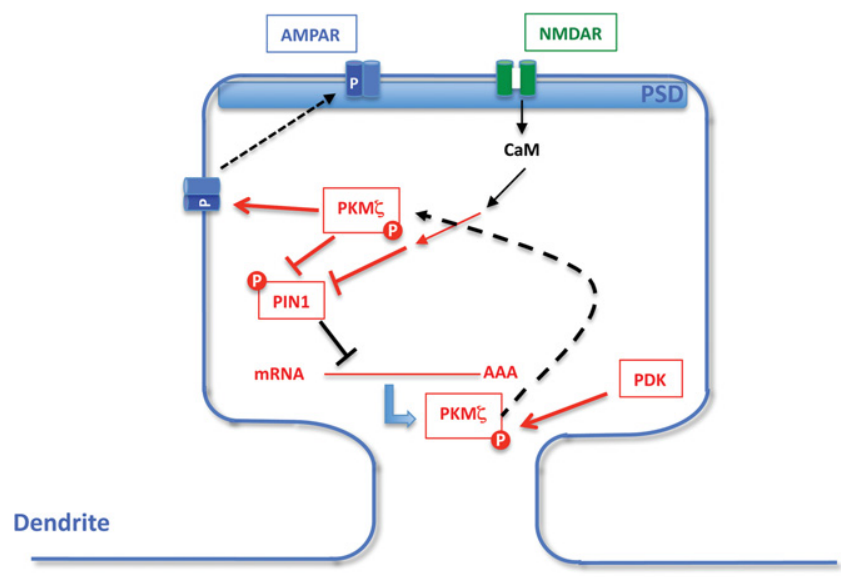

Figure 5. Model of the role of $\mathrm{PKM} \zeta$ in memory storage. Local synthesis of $\mathrm{PKM} \zeta$ is inhibited by PIN1. NMDA receptor stimulation relieves this inhibition in an unknown manner. Once PKM $\zeta$ is synthesized, the kinase is constitutively active. Its activity is further increased by phosphorylation by PDK. PKM $\zeta$ phosphorylates the GluA2 subunit in AMPA receptors leading to translocation of these receptors into the PSD. Additionally, PKM $\zeta$ inhibits PIN1 so local translation continues to persistently supply the activated synapse with PKM $\zeta$, overcoming protein turnover. Red lines indicate phosphorylations and dashed arrows illustrate translocation of the protein. The model is according to Sacktor (2011).
ZIP, indicating that ZIP blocks a molecule distinct from PKM $\zeta$ that is required for LTP maintenance (Volk et al. 2013). Importantly, normal CA1 LTP was also detected in conditional PKC $\zeta / \mathrm{PKM} \zeta$ KO mice (Volk et al. 2013). These conditional mutants were obtained after a very short treatment with tamoxifen to induce Cre recombination, preventing the possibility of compensatory effects. Surprisingly, the conventional PKC $/$ PKM $\zeta$ KO mice have normal memory storage in a number of hippocampus-dependent tasks including spatial tasks and trace fear conditioning (Lee et al. 2013; Volk et al. 2013). Further, like in the LTP experiments, ZIP treatment erases an established reward memory in $\mathrm{PKC} \zeta / \mathrm{PKM} \zeta$ $\mathrm{KO}$ mice, indicating that ZIP blocks a memory storing molecule distinct from PKM $\zeta$ (Lee et al. 2013). At this stage it remains speculative as to what molecules are blocked by ZIP, but they may include another PKC isoform (Glanzman 2013). Despite the ZIP controversy, molecular biological studies have suggested that $\mathrm{PKM} \zeta$ may still contribute to memory storage (Shema et al. 2011). These studies showed that overexpression of PKM $\zeta$ enhances two distinct, consolidated LTMs. Moreover, injection of PKM $\zeta$ antisense oligonucleotides before aversive conditioning blocks LTM but not STM (Tsokas et al. 2012).

\section{Fyn and other kinases}

Further kinases are probably involved in learning and memory. For example, the tyrosine kinase fyn appears to contribute to memory formation. One of the first KO studies in the learning and memory field claimed that fyn is required for spatial memory formation in the water maze (Grant et al. 1992). However, later it was established that the impairments in the water maze are due to swimming deficits that can be overcome by mechanically stimulating the hind paws (Huerta et al. 1996). Nonetheless, during contextual fear memory formation fyn is specifically activated in the hippocampus for $\sim 40 \mathrm{~min}$ (Isosaka et al. 2008). Accordingly, fyn KO mice are impaired in STM and LTM after contextual fear conditioning (Isosaka et al. 2008). After conditioning, fyn phosphorylates GluN2B at tyrosine-1472 (Isosaka et al. 2008), a phosphorylation event that promotes GluN2B surface expression at synapses (Prybylowski et al. 2005).

Another example is casein kinase 2 (CK2). Spatial memory formation in the water maze is associated with down-regulation of CK2 activity in hippocampal area CA1 (Chao et al. 2007). Overexpression of a dominant-negative form of CK2 in the CA1 region enhances spatial memory formation (Chao et al. 2007). Thus, CK2 activity appears to constrain spatial memory formation. A final example is p21-activated kinase (PAK). PAK is a regulator of actin remodeling that is required for synaptogenesis. Forebrain-restricted expression of a dominant-negative form of PAK impairs contextual fear LTM (Hayashi et al. 2004). In these mutants basal synapse numbers are normal in the hippocampus (Hayashi et al. 2004), but the authors did not test whether conditioning-induced synaptogenesis is impaired (compare with, Radwanska et al. 2011).

\section{Conclusion}

For more than $20 \mathrm{yr}$, the functions of protein kinases in mammalian learning and memory have been studied. It has become clear that these enzymes are critically important for learning and memory, as summarized in Table 1. Currently, most is known about the roles of kinases in memory formation. During memory formation kinase action can be classified into one of two steps: (1) regulation of ion channel density and/or conductivity which impacts on synaptic transmission (e.g., regulation of AMPA receptor trafficking) (Figs. 1,5), and (2) regulation of gene transcription and/or 
Table 1. Simplified summary of kinase involvement in mammalian learning and memory

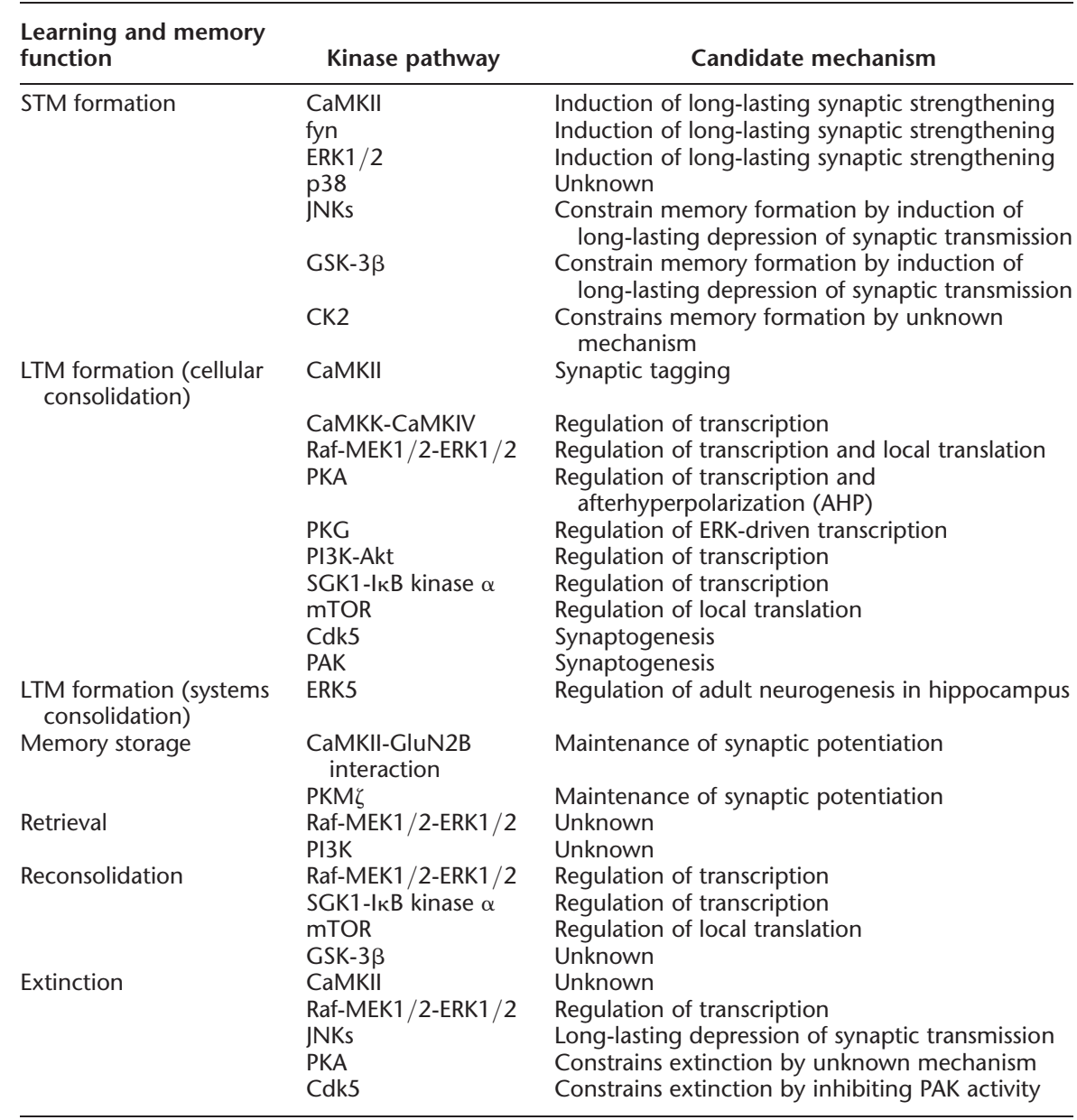

receptor trafficking, regulation of ion channel conductivity, and actin polymerization. Although CaMKII stands out as a kinase for initial memory formation, no single kinase appears to be solely responsible for activation of gene transcription and protein synthesis during memory consolidation. Instead, a sophisticated interplay of kinases (kinase cascades) induces gene transcription and protein synthesis. These kinase cascades amplify incoming signaling to reach a threshold to induce transcription and translation. Different kinase cascades have distinct activation features, such as the CaM kinase and MAP kinase cascades, suggesting that the cascades respond to different signals. In addition to amplifying signals, kinase cascades also have coincidence detection properties. Coincidence detection may serve the purpose to set a threshold so that noise signals cannot induce transcription and translation. Finally, regarding memory storage, it is appealing to think of a perpetuating kinase mechanism that persistently keeps synapses in an activated state and that overcomes molecular turnover (Crick 1984; Lisman 1985). Accordingly, the current candidate kinases for memory storage are CaMKII (interacting with the NMDA receptor) (Sanhueza and Lisman 2013) and PKC isoforms that have no regulatory domains and that are locally translated (Glanzman 2013).

The known learning and memoryrelated kinases are multifunctional in that they phosphorylate multiple substrates. It is hoped that future phospho-

local translation (Figs. 2-4) which impact on structural growth of existing synapses and/or synaptogenesis. In this review we also include evidence for the roles of kinases in memory processes other than memory formation, because the underlying molecular mechanisms are likely to be different. For example, extinction, but not memory formation, requires protein degradation at synapses (Lee et al. 2008). Protein degradation may be regulated by kinases that are not needed for memory formation. Similarly, extinction, but not memory formation, may involve depotentiation of synapses. In agreement with this thinking, some kinases are involved in extinction but not in memory formation, as shown in Table 1. A further justification for distinguishing between memory processes is that a given kinase may have different functions in distinct memory processes. For example, the same kinase may phosphorylate different substrates during memory formation vs. retrieval.

Regarding the known function of kinases in memory formation, the question arises whether all kinases are equally important or whether a specific kinase stands out. In our view, CaMKII stands out as a key player for initial memory formation. For example, mice lacking $\alpha$ CaMKII autophosphorylation have the most severe deficit in hippocampus-dependent memory formation ever detected in a mutant mouse line, without affecting performance or other types of procedural learning (Giese et al. 1998; Need and Giese 2003; Irvine et al. 2005). CaMKII may have such a prominent role in memory formation due to its complex biochemistry that can regulate several processes at the synapses, including proteomic studies will identify phosphorylation events relevant for learning and memory. The importance of such phosphorylations will need to be tested with KI mouse models that specifically inactivate a candidate phosphorylation, as was done for the T286 autophosphorylation of $\alpha$ CaMKII (Giese et al. 1998). Additionally, the functions of many brain kinases are not known yet. Therefore, it is possible that so far unappreciated kinases will emerge as novel players in learning and memory. Finally, not much is known about kinase dysfunction in human diseases with associated learning and memory impairments. It appears intuitive that in some diseases, mutations in kinase genes cause or enhance the risk of learning and memory impairments, an idea that will need testing.

\section{Acknowledgments}

We thank Dr. Jeffrey Vernon for critically reading an earlier version of this paper, and the Biotechnology and Biological Sciences Research Council (BBSRC), the Medical Research Council (MRC), and the National Institutes of Health (NIH) for generous support.

\section{References}

Abel T, Nguyen PV. 2008. Regulation of hippocampus-dependent memory by cyclic AMP-dependent protein kinase. Prog Brain Res 169: 97-115. Abel T, Nguyen PV, Barad M, Deuel TA, Kandel ER, Bourtchouladze R. 1997. Genetic demonstration of a role for PKA in the late phase 
of LTP and in hippocampus-based long-term memory. Cell 88: $615-626$.

Abeliovich A, Paylor R, Chen C, Kim JJ, Wehner JM, Tonegawa S. 1993. PKC $\gamma$ Mutant mice exhibit mild deficits in spatial and contextual learning. Cell 75: $1263-1271$.

Adaikkan C, Rosenblum K. 2012. The role of protein phosphorylation in the gustatory cortex and amygdala during taste learning. Exp Neurobiol 21: $37-51$.

Adams JP, Sweatt JD. 2002. Molecular psychology: Roles for the ERK MAP kinase cascade in memory. Annu Rev Pharmacol Toxicol 42: 135-163.

Ahi J, Radulovic J, Spiess J. 2004. The role of hippocampal signaling cascades in consolidation of fear memory. Behav Brain Res 149: 17-31.

Alonso M, Bevilaqua LR, Izquierdo I, Medina JH, Cammarota M. 2003. Memory formation requires p38MAPK activity in the rat hippocampus. Neuroreport 14: 1989-1992.

Angelo M, Plattner F, Irvine EE, Giese KP. 2003. Improved reversal learning and altered fear conditioning in transgenic mice with regionally restricted p25 expression. Eur J Neurosci 18: 423-431.

Angelo M, Plattner F, Giese KP. 2006. Cyclin-dependent kinase 5 in synaptic plasticity, learning and memory. J Neurochem 99: 353-370.

Antion MD, Merhav M, Hoeffer CA, Reis G, Kozma SC, Thomas G, Schuman EM, Rosenblum K, Klann E. 2008. Removal of S6K1 and S6K2 leads to divergent alterations in learning, memory, and synaptic plasticity. Learn Mem 15: 29-38.

Antunes-Martins A, Mizuno K, Irvine EE, Lepicard EM, Giese KP. 2007. Sex-dependent up-regulation of two splicing factors, Psf and Srp20, during hippocampal memory formation. Learn Mem 14: 693-702.

Atkins CM, Selcher JC, Petraitis JJ, Trzaskos JM, Sweatt JD. 1998. The MAPK cascade is required for mammalian associative learning. Nat Neurosci $\mathbf{1}$ : 602-609.

Barad M, Bourtchouladze R, Winder DG, Golan H, Kandel E. 1998. Rolipram, a type IV-specific phosphodiesterase inhibitor, facilitates the establishment of long-lasting long-term potentiation and improves memory. Proc Natl Acad Sci 95: 15020-15025.

Barros DM, Mello e Souza T, de Souza MM, Choi H, DeDavid e Silva T, Lenz G, Medina JH, Izquierdo I. 2001. LY294002, an inhibitor of phosphoinositide 3-kinase given into rat hippocampus impairs acquisition, consolidation and retrieval of memory for one-trial step-down inhibitory avoidance. Behav Pharmacol 12: 629-634.

Bartsch D, Casadio A, Karl KA, Serodio P, Kandel ER. 1998. CREB1 encodes a nuclear activator, a repressor, and a cytoplasmic modulator that form a regulatory unit critical for long-term facilitation. Cell 95: 211-223.

Bejar R, Yasuda R, Krugers H, Hood K, Mayford M. 2002. Transgenic calmodulin-dependent protein kinase II activation: Dose-dependent effects on synaptic plasticity, learning, and memory. J Neurosci 22: $5719-5726$.

Bekinschtein P, Katche C, Slipczuk LN, Igaz LM, Cammarota M, Izquierdo I, Medina JH. 2007. mTOR signaling in the hippocampus is necessary for memory formation. Neurobiol Learn Mem 87: 303-307.

Bernabeu R, Bevilaqua L, Ardenghi P, Bromberg E, Schmitz P, Bianchin M, Izquierdo I, Medina JH. 1997. Involvement of hippocampal cAMP/ cAMP-dependent protein kinase signaling pathways in a late memory consolidation phase of aversively motivated learning in rats. Proc Natl Acad Sci 94: 7041-7046.

Besnard A, Galan-Rodriguez B, Vanhoutte P, Caboche J. 2011. Elk-1 a transcription factor with multiple facets in the brain. Front Neurosci 5: 35 .

Bevilaqua LR, Kerr DS, Medina JH, Izquierdo I, Cammarota M. 2003. Inhibition of hippocampal Jun $N$-terminal kinase enhances short-term memory but blocks long-term memory formation and retrieval of an inhibitory avoidance task. Eur J Neurosci 17: 897-902.

Bevilaqua LR, Rossato JI, Clarke JH, Medina JH, Izquierdo I, Cammarota M. 2007. Inhibition of c-Jun $N$-terminal kinase in the CA1 region of the dorsal hippocampus blocks extinction of inhibitory avoidance memory. Behav Pharmacol 18: 483-489.

Bito H, Deisseroth K, Tsien RW. 1996. CREB phosphorylation and dephosphorylation: $\mathrm{A} \mathrm{Ca}^{2+}$ - and stimulus duration-dependent switch for hippocampal gene expression. Cell 87: 1203-1214.

Blaeser F, Sanders MJ, Truong N, Ko S, Wu LJ, Wozniak DF, Fanselow MS, Zhuo M, Chatila TA. 2006. Long-term memory deficits in Pavlovian fear conditioning in $\mathrm{Ca}^{2+} /$ calmodulin kinase kinase $\alpha$-deficient mice. Mol Cell Biol 26: 9105-9115.

Bonini JS, Da Silva WC, Bevilaqua LR, Medina JH, Izquierdo I, Cammarota M. 2007. On the participation of hippocampal PKC in acquisition, consolidation and reconsolidation of spatial memory. Neuroscience 147: 37-45.

Borgesius NZ, van Woerden GM, Buitendijk GH, Keijzer N, Jaarsma D, Hoogenraad CC, Elgersma Y. 2011. $\beta$ CaMKII plays a nonenzymatic role in hippocampal synaptic plasticity and learning by targeting $\alpha$ CaMKII to synapses. J Neurosci 31: 10141-10148.

Bourtchouladze R, Abel T, Berman N, Gordon R, Lapidus K, Kandel ER. 1998. Different training procedures recruit either one or two critical periods for contextual memory consolidation, each of which requires protein synthesis and PKA. Learn Mem 5: 365-374.

Brandon EP, Idzerda RL, McKnight GS. 1997. PKA isoforms, neural pathways, and behaviour: Making the connection. Curr Opin Neurobiol 7: 397-403.

Buard I, Coultrap SJ, Freund RK, Lee YS, Dell'Acqua ML, Silva AJ, Bayer KU. 2010. CaMKII "autonomy" is required for initiating but not for maintaining neuronal long-term information storage. J Neurosci 30: $8214-8220$.

Cammarota M, Bernabeu R, Levi De Stein M, Izquierdo I, Medina JH. 1998. Learning-specific, time-dependent increases in hippocampal $\mathrm{Ca}^{2+} /$ calmodulin-dependent protein kinase II activity and AMPA GluR1 subunit immunoreactivity. Eur J Neurosci 10: 2669-2676.

Cammarota M, Bevilaqua LR, Barros DM, Vianna MR, Izquierdo LA, Medina JH, Izquierdo I. 2005. Retrieval and the extinction of memory. Cell Mol Neurobiol 25: 465-474.

Cestari V, Costanzi M, Castellano C, Rossi-Arnaud C. 2006. A role for ERK2 in reconsolidation of fear memories in mice. Neurobiol Learn Mem 86: $133-143$.

Chao CC, Ma YL, Lee EH. 2007. Protein kinase CK2 impairs spatial memory formation through differential cross talk with PI-3 kinase signaling: Activation of Akt and inactivation of SGK1. J Neurosci 27: 6243-6248.

Chen X, Garelick MG, Wang H, Lil V, Athos J, Storm DR. 2005. PI3 kinase signaling is required for retrieval and extinction of contextual memory. Nat Neurosci 8: 925-931.

Chwang WB, Arthur JS, Schumacher A, Sweatt JD. 2007. The nuclear kinase mitogen- and stress-activated protein kinase 1 regulates hippocampal chromatin remodeling in memory formation. J Neurosci 27: 12732-12742.

Costa RM, Federov NB, Kogan JH, Murphy GG, Stern J, Ohno M, Kucherlapati R, Jacks T, Silva AJ. 2002. Mechanism for the learning deficits in a mouse model of neurofibromatosis type 1. Nature 415: 526-530.

Coultrap SJ, Bayer KU. 2012. CaMKII regulation in information processing and storage. Trends Neurosci 35: 607-618

Crick F. 1984. Memory and molecular turnover. Nature 312: 101.

Cui Y, Costa RM, Murphy GG, Elgersma Y, Zhu Y, Gutmann DH, Parada LF, Mody I, Silva AJ. 2008. Neurofibromin regulation of ERK signaling modulates GABA release and learning. Cell 135: 549-560.

Dash PK, Mach SA, Blum S, Moore AN. 2002. Intrahippocampal wortmannin infusion enhances long-term spatial and contextual memories. Learn Mem 9: 167-177.

Davis S, Laroche S. 2006. Mitogen-activated protein kinase/extracellular regulated kinase signalling and memory stabilization: A review. Genes Brain Behav 5 Suppl 2: 61-72.

Dudai Y. 1988. Neurogenetic dissection of learning and short-term memory in Drosophila. Annu Rev Neurosci 11: 537-563.

Duvarci S, Nader K, LeDoux JE. 2005. Activation of extracellular signal-regulated kinase- mitogen-activated protein kinase cascade in the amygdala is required for memory reconsolidation of auditory fear conditioning. Eur J Neurosci 21: 283-289.

Easton AC, Lourdusamy A, Loth E, Torro R, Giese KP, Kornhuber J, de Quervain DJ, Papassotiropoulos A, Fernandes C, Muller CP, et al. 2012. CAMK2A polymorphisms predict working memory performance in humans. Mol Psychiatry doi:10.1038/mp.2012.114.

Ehninger D, Silva AJ. 2011. Rapamycin for treating tuberous sclerosis and autism spectrum disorders. Trends Mol Med 17: 78-87.

Ehninger D, Han S, Shilyansky C, Zhou Y, Li W, Kwiatkowski DJ, Ramesh V, Silva AJ. 2008. Reversal of learning deficits in a $\mathrm{Tsc}^{2+/-}$ mouse model of tuberous sclerosis. Nat Med 14: 843-848.

Elgersma Y, Fedorov NB, Ikonen S, Choi ES, Elgersma M, Carvalho OM, Giese KP, Silva AJ. 2002. Inhibitory autophosphorylation of CaMKII controls PSD association, plasticity, and learning. Neuron 36: $493-505$.

Elgersma Y, Sweatt JD, Giese KP. 2004. Mouse genetic approaches to investigating calcium/calmodulin-dependent protein kinase II function in plasticity and cognition. J Neurosci 24: 8410-8415.

Engmann O, Hortobagyi T, Pidsley R, Troakes C, Bernstein HG, Kreutz MR, Mill J, Nikolic M, Giese KP. 2011a. Schizophrenia is associated with dysregulation of a Cdk5 activator that regulates synaptic protein expression and cognition. Brain 134: 2408-2421.

Engmann O, Hortobagyi T, Thompson AJ, Guadagno J, Troakes C, Soriano S, Al-Sarraj S, Kim Y, Giese KP. 2011b. Cyclin-dependent kinase 5 activator p 25 is generated during memory formation and is reduced at an early stage in Alzheimer's disease. Biol Psychiatry 70: 159-168.

Feig LA. 2011. Regulation of neuronal function by Ras-GRF exchange factors. Genes Cancer 2: 306-319.

Fischer A, Sananbenesi F, Schrick C, Spiess J, Radulovic J. 2002. Cyclin-dependent kinase 5 is required for associative learning. $J$ Neurosci 22: 3700-3707.

Fischer A, Sananbenesi F, Schrick C, Spiess J, Radulovic J. 2003. Regulation of contextual fear conditioning by baseline and inducible 
septo-hippocampal cyclin-dependent kinase 5. Neuropharmacology 44: $1089-1099$

Fischer A, Sananbenesi F, Pang PT, Lu B, Tsai LH. 2005. Opposing roles of transient and prolonged expression of p 25 in synaptic plasticity and hippocampus-dependent memory. Neuron 48: 825-838.

Fischer A, Radulovic M, Schrick C, Sananbenesi F, Godovac-Zimmermann J, Radulovic J. 2007. Hippocampal Mek/Erk signaling mediates extinction of contextual freezing behavior. Neurobiol Learn Mem 87: 149-158.

Fortin DA, Srivastava T, Dwarakanath D, Pierre P, Nygaard S, Derkach VA, Soderling TR. 2012. Brain-derived neurotrophic factor activation of CaM-kinase kinase via transient receptor potential canonical channels induces the translation and synaptic incorporation of GluA1-containing calcium-permeable AMPA receptors. J Neurosci 32: $8127-8137$

Frankland PW, Bontempi B, Talton LE, Kaczmarek L, Silva AJ. 2004. The involvement of the anterior cingulate cortex in remote contextual fear memory. Science 304: 881-883.

Fujio J, Hosono H, Ishiguro K, Ikegami S, Fujita SC. 2007. $\tau$ Phosphorylation in the mouse brain during aversive conditioning. Neurochem Int 51: $200-208$.

Fukazawa Y, Saitoh Y, Ozawa F, Ohta Y, Mizuno K, Inokuchi K. 2003. Hippocampal LTP is accompanied by enhanced F-actin content within the dendritic spine that is essential for late LTP maintenance in vivo. Neuron 38: 447-460.

Fukunaga K, Stoppini L, Miyamoto E, Muller D. 1993. Long-term potentiation is associated with an increased activity of $\mathrm{Ca}^{2+} /$ calmodulin-dependent protein kinase II. J Biol Chem 268: 7863-7867.

Fukushima H, Maeda R, Suzuki R, Suzuki A, Nomoto M, Toyoda H, Wu LJ, $\mathrm{Xu} \mathrm{H}$, Zhao MG, Ueda K, et al. 2008. Upregulation of calcium/ calmodulin-dependent protein kinase IV improves memory formation and rescues memory loss with aging. J Neurosci 28: 9910-9919.

Giese KP. 2009. GSK-3: A key player in neurodegeneration and memory. IUBMB Life 61: 516-521.

Giese KP. 2012. Long-term potentiation and memory. In Memory mechanisms in health and disease (ed. Giese KP), pp. 1-17. World Scientific Publishing, Singapore.

Giese KP, Fedorov NB, Filipkowski RK, Silva AJ. 1998. Autophosphorylation at Thr286 of the $\alpha$ calcium-calmodulin kinase II in LTP and learning. Science 279: 870-873.

Giovannini MG. 2006. The role of the extracellular signal-regulated kinase pathway in memory encoding. Rev Neurosci 17: 619-634.

Glanzman DL. 2013. PKM and the maintenance of memory. F1000 Biol Reports 5: 4 .

Grant SG, O'Dell TJ, Karl KA, Stein PL, Soriano P, Kandel ER. 1992. Impaired long-term potentiation, spatial learning, and hippocampal development in fyn mutant mice. Science 258: 1903-1910.

Gresack JE, Schafe GE, Orr PT, Frick KM. 2009. Sex differences in contextual fear conditioning are associated with differential ventral hippocampal extracellular signal-regulated kinase activation. Neuroscience 159: $451-467$.

Gruart A, Munoz MD, Delgado-Garcia JM. 2006. Involvement of the CA3-CA1 synapse in the acquisition of associative learning in behaving mice. J Neurosci 26: 1077-1087.

Guan JS, Su SC, Gao J, Joseph N, Xie Z, Zhou Y, Durak O, Zhang L, Zhu JJ, Clauser KR, et al. 2011. Cdk5 is required for memory function and hippocampal plasticity via the cAMP signaling pathway. PLoS One 6: e25735.

Halt AR, Dallapiazza RF, Zhou Y, Stein IS, Qian H, Juntti S, Wojcik S, Brose N, Silva AJ, Hell JW. 2012. CaMKII binding to GluN2B is critical during memory consolidation. EMBO J 31: 1203-1216.

Hanson PI, Schulman H. 1992. Neuronal $\mathrm{Ca}^{2+} /$ calmodulin-dependent protein kinases. Аnпu Rev Biochem 61: 559-601.

Hawasli AH, Benavides DR, Nguyen C, Kansy JW, Hayashi K, Chambon P, Greengard P, Powell CM, Cooper DC, Bibb JA. 2007. Cyclin-dependent kinase 5 governs learning and synaptic plasticity via control of NMDAR degradation. Nat Neurosci 10: 880-886.

Hayashi ML, Choi SY, Rao BS, Jung HY, Lee HK, Zhang D, Chattarji S, Kirkwood A, Tonegawa S. 2004. Altered cortical synaptic morphology and impaired memory consolidation in forebrain-specific dominant-negative PAK transgenic mice. Neuron 42: 773-787.

Hernandez F, Borrell J, Guaza C, Avila J, Lucas JJ. 2002. Spatial learning deficit in transgenic mice that conditionally over-express GSK-3 $\beta$ in the brain but do not form $\tau$ filaments. J Neurochem 83: 1529-1533.

Hernandez AI, Blace N, Crary JF, Serrano PA, Leitges M, Libien JM, Weinstein G, Tcherapanov A, Sacktor TC. 2003. Protein kinase M $\zeta$ synthesis from a brain mRNA encoding an independent protein kinase $\mathrm{C} \beta$ catalytic domain. Implications for the molecular mechanism of memory. J Biol Chem 278: 40305-40316.

Herry C, Trifilieff P, Micheau J, Luthi A, Mons N. 2006. Extinction of auditory fear conditioning requires MAPK/ERK activation in the basolateral amygdala. Eur J Neurosci 24: 261-269.
Ho N, Liauw JA, Blaeser F, Wei F, Hanissian S, Muglia LM, Wozniak DF, Nardi A, Arvin KL, Holtzman DM, et al. 2000. Impaired synaptic plasticity and cAMP response element-binding protein activation in $\mathrm{Ca}^{2+} /$ calmodulin-dependent protein kinase type IV/Gr-deficient mice. J Neurosci 20: 6459-6472.

Hoeffer CA, Klann E. 2010. mTOR signaling: At the crossroads of plasticity, memory and disease. Trends Neurosci 33: 67-75.

Hoeffer CA, Tang W, Wong H, Santillan A, Patterson RJ, Martinez LA, Tejada-Simon MV, Paylor R, Hamilton SL, Klann E. 2008. Removal of FKBP12 enhances mTOR-Raptor interactions, LTP, memory, and perseverative/repetitive behavior. Neuron 60: $832-845$.

Hong JG, Kim DH, Lee CH, Park SJ, Kim JM, Cai M, Jang DS, Ryu JH. 2012. GSK-3 $\beta$ activity in the hippocampus is required for memory retrieval. Neurobiol Learn Mem 98: 122-129.

Hooper C, Markevich V, Plattner F, Killick R, Schofield E, Engel T, Hernandez F, Anderton B, Rosenblum K, Bliss T, et al. 2007. Glycogen synthase kinase-3 inhibition is integral to long-term potentiation. Eur I Neurosci 25: 81-86.

Horwood JM, Dufour F, Laroche S, Davis S. 2006. Signalling mechanisms mediated by the phosphoinositide 3-kinase/Akt cascade in synaptic plasticity and memory in the rat. Eur J Neurosci 23: 3375-3384.

Huang W, Zhu PJ, Zhang S, Zhou H, Stoica L, Galiano M, Krnjevic K, Roman G, Costa-Mattioli M. 2013. mTORC2 controls actin polymerization required for consolidation of long-term memory. Nat Neurosci 16: 441-448.

Huerta PT, Scearce KA, Farris SM, Empson RM, Prusky GT. 1996. Preservation of spatial learning in fyn tyrosine kinase knockout mice. Neuroreport 7: 1685-1689.

Inokuchi K. 2011. Adult neurogenesis and modulation of neural circuit function. Curr Opin Neurobiol 21: 360-364.

Irvine EE, Vernon J, Giese KP. 2005. $\alpha$ CaMKII autophosphorylation contributes to rapid learning but is not necessary for memory. Nat Neurosci 8: 411-412.

Irvine EE, von Hertzen LS, Plattner F, Giese KP. 2006. $\alpha$ CaMKII autophosphorylation: A fast track to memory. Trends Neurosci 29: 459-465.

Irvine EE, Danhiez A, Radwanska K, Nassim C, Lucchesi W, Godaux E, Ris L, Giese KP. 2011. Properties of contextual memory formed in the absence of $\alpha$ CaMKII autophosphorylation. Mol Brain 4: 8 .

Isiegas C, Park A, Kandel ER, Abel T, Lattal KM. 2006. Transgenic inhibition of neuronal protein kinase A activity facilitates fear extinction. $J$ Neurosci 26: $12700-12707$.

Isosaka T, Hattori K, Kida S, Kohno T, Nakazawa T, Yamamoto T, Yagi T, Yuasa S. 2008. Activation of Fyn tyrosine kinase in the mouse dorsal hippocampus is essential for contextual fear conditioning. Eur J Neurosci 28: 973-981.

Jaken S. 1996. Protein kinase C isozymes and substrates. Curr Opin Cell Biol 8: $168-173$.

Jobim PF, Pedroso TR, Christoff RR, Werenicz A, Maurmann N, Reolon GK, Roesler R. 2012. Inhibition of mTOR by rapamycin in the amygdala or hippocampus impairs formation and reconsolidation of inhibitory avoidance memory. Neurobiol Learn Mem 97: 105-112.

Kandel ER. 2012. The molecular biology of memory: cAMP, PKA, CRE, CREB-1, CREB-2, and CPEB. Mol Brain 5: 14 .

Kang H, Sun LD, Atkins CM, Soderling TR, Wilson MA, Tonegawa S. 2001. An important role of neural activity-dependent CaMKIV signaling in the consolidation of long-term memory. Cell 106: 771-783.

Kelleher RJ III, Govindarajan A, Jung HY, Kang H, Tonegawa S. 2004 Translational control by MAPK signaling in long-term synaptic plasticity and memory. Cell 116: 467-479.

Kelly A, Laroche S, Davis S. 2003. Activation of mitogen-activated protein kinase/extracellular signal-regulated kinase in hippocampal circuitry is required for consolidation and reconsolidation of recognition memory. J Neurosci 23: 5354-5360.

Kim SY, Hwang GS, Han H, Cho M. 2011. Phosphorylation alters backbone conformational preferences of serine and threonine peptides. Proteins 79: $3155-3165$.

Kimura R, Silva AJ, Ohno M. 2008a. Autophosphorylation of $\alpha$ CaMKII is differentially involved in new learning and unlearning mechanisms of memory extinction. Learn Mem 15: 837-843.

Kimura T, Yamashita S, Nakao S, Park JM, Murayama M, Mizoroki T, Yoshiike Y, Sahara N, Takashima A. 2008b. GSK-3ß is required for memory reconsolidation in adult brain. PLoS One 3: e3540.

Kwapis JL, Jarome TJ, Lonergan ME, Helmstetter FJ. 2009. Protein kinase M $\zeta$ maintains fear memory in the amygdala but not in the hippocampus. Behav Neurosci 123: 844-850.

Lai KO, Ip NY. 2009. Recent advances in understanding the roles of Cdk5 in synaptic plasticity. Biochim Biophys Acta 1792: 741-745.

Lai KO, Wong AS, Cheung MC, Xu P, Liang Z, Lok KC, Xie H, Palko ME, Yung WH, Tessarollo L, et al. 2012. TrkB phosphorylation by Cdk5 is required for activity-dependent structural plasticity and spatial memory. Nat Neurosci 15: 1506-1515. 
Languille S, Davis S, Richer P, Alcacer C, Laroche S, Hars B. 2009. Extracellular signal-regulated kinase activation is required for consolidation and reconsolidation of memory at an early stage of ontogenesis. Eur I Neurosci 30: 1923-1930.

Lee CT, Tyan SW, Ma YL, Tsai MC, Yang YC, Lee EH. 2006. Serum- and glucocorticoid-inducible kinase (SGK) is a target of the MAPK/ERK signaling pathway that mediates memory formation in rats. Eur $J$ Neurosci 23: $1311-1320$.

Lee CT, Ma YL, Lee EH. 2007. Serum- and glucocorticoid-inducible kinase1 enhances contextual fear memory formation through down-regulation of the expression of Hes5. J Neurochem 100: 1531-1542.

Lee SH, Choi JH, Lee N, Lee HR, Kim JI, Yu NK, Choi SL, Lee SH, Kim H, Kaan BK. 2008. Synaptic protein degradation underlies destabilization of retrieved fear memory. Science 319: 1253-1256.

Lee SJ, Escobedo-Lozoya Y, Szatmari EM, Yasuda R. 2009. Activation of CaMKII in single dendritic spines during long-term potentiation. Nature 458: 299-304.

Lee AM, Kanter BR, Wang D, Lim JP, Zou ME, Qiu C, McMahon T, Dadgar J, Fischbach-Weiss SC, Messing RO. 2013. Prkcz null mice show normal learning and memory. Nature 493: 416-419.

Lengyel I, Voss K, Cammarota M, Bradshaw K, Brent V, Murphy KP, Giese KP, Rostas JA, Bliss TV. 2004. Autonomous activity of CaMKII is only transiently increased following the induction of long-term potentiation in the rat hippocampus. Eur J Neurosci 20: 3063-3072.

Lepicard FM, Mizuno K, Antunes-Martins A, von Hertzen LS, Giese KP. 2006. An endogenous inhibitor of calcium/calmodulin-dependent kinase II is up-regulated during consolidation of fear memory. Eur J Neurosci 23: 3063-3070.

Lin YC, Redmond L. 2008. CaMKII $\beta$ binding to stable F-actin in vivo regulates F-actin filament stability. Proc Natl Acad Sci 105: 15791-15796.

Lin CH, Yeh SH, Lu KT, Leu TH, Chang WC, Gean PW. 2001. A role for the PI-3 kinase signaling pathway in fear conditioning and synaptic plasticity in the amygdala. Neuron 31: 841-851.

Lisman JE. 1985. A mechanism for memory storage insensitive to molecular turnover: A bistable autophosphorylating kinase. Proc Natl Acad Sci 82: 3055-3057.

Lisman J. 1994. The CaM kinase II hypothesis for the storage of synaptic memory. Trends Neurosci 17: 406-412

Lisman J, Schulman H, Cline H. 2002. The molecular basis of CaMKII function in synaptic and behavioural memory. Nat Rev Neurosci 3: $175-190$.

Lisman J, Yasuda R, Raghavachari S. 2012. Mechanisms of CaMKII action in long-term potentiation. Nat Rev Neurosci 13: 169-182.

Liu RY, Fioravante D, Shah S, Byrne JH. 2008. cAMP response element-binding protein 1 feedback loop is necessary for consolidation of long-term synaptic facilitation in Aplysia. J Neurosci 28: 1970-1976.

Lu KT, Walker DL, Davis M. 2001. Mitogen-activated protein kinase cascade in the basolateral nucleus of amygdala is involved in extinction of fear-potentiated startle. J Neurosci 21: pRC162.

Lubin FD, Sweatt JD. 2007. The IкB kinase regulates chromatin structure during reconsolidation of conditioned fear memories. Neuron 55: 942-957.

Lucchesi W, Mizuno K, Giese KP. 2011. Novel insights into CaMKII function and regulation during memory formation. Brain Res Bull 85: $2-8$.

Migues PV, Hardt O, Wu DC, Gamache K, Sacktor TC, Wang YT, Nader K. 2010. PKM $\zeta$ maintains memories by regulating GluR2-dependent AMPA receptor trafficking. Nat Neurosci 13: 630-634.

Miller S, Yasuda M, Coats JK, Jones Y, Martone ME, Mayford M. 2002. Disruption of dendritic translation of CaMKII $\alpha$ impairs stabilization of synaptic plasticity and memory consolidation. Neuron 36: 507-519.

Mizuno K, Giese KP. 2010. Towards a molecular understanding of sex differences in memory formation. Trends Neurosci 33: 285-291.

Mizuno K, Ris L, Sanchez-Capelo A, Godaux E, Giese KP. 2006. $\mathrm{Ca}^{2+}$ / calmodulin kinase kinase $\alpha$ is dispensable for brain development but is required for distinct memories in male, though not in female, mice. $\mathrm{Mol}$ Cell Biol 26: 9094-9104.

Mizuno K, Antunes-Martins A, Ris L, Peters M, Godaux E, Giese KP. 2007. Calcium/calmodulin kinase kinase $\beta$ has a male-specific role in memory formation. Neuroscience 145: 393-402.

Mizuno K, Dempster E, Mill J, Giese KP. 2012. Long-lasting regulation of hippocampal Bdnf gene transcription after contextual fear conditioning. Genes Brain Behav 11: 651-659.

Moncada D, Viola H. 2007. Induction of long-term memory by exposure to novelty requires protein synthesis: Evidence for a behavioral tagging. J Neurosci 27: 7476-7481.

Moncada D, Ballarini F, Martinez MC, Frey JU, Viola H. 2011. Identification of transmitter systems and learning tag molecules involved in behavioral tagging during memory formation. Proc Natl Acad Sci 108: 12931-12936.
Morozov A, Muzzio IA, Bourtchouladze R, Van-Strien N, Lapidus K, Yin D, Winder DG, Adams JP, Sweatt JD, Kandel ER. 2003. Rap1 couples cAMP signaling to a distinct pool of p42/44MAPK regulating excitability, synaptic plasticity, learning, and memory. Neuron 39: 309-325.

Musumeci G, Sciarretta C, Rodriguez-Moreno A, Al Banchaabouchi M, Negrete-Diaz V, Costanzi M, Berno V, Egorov AV, von Bohlen Und Halbach O, Cestari V, et al. 2009. TrkB modulates fear learning and amygdalar synaptic plasticity by specific docking sites. J Neurosci 29: 10131-10143

Nader K, Hardt O. 2009. A single standard for memory: The case for reconsolidation. Nat Rev Neurosci 10: 224-234.

Need AC, Giese KP. 2003. Handling and environmental enrichment do not rescue learning and memory impairments in $\alpha$ CamKII(T286A) mutant mice. Genes Brain Behav 2: 132-139.

Obara Y, Horgan AM, Stork PJ. 2007. The requirement of Ras and Rap1 for the activation of ERKs by cAMP, PACAP, and $\mathrm{KCl}$ in cerebellar granule cells. J Neurochem 101: 470-482.

Oh MM, McKay BM, Power JM, Disterhoft JF. 2009. Learning-related postburst afterhyperpolarization reduction in CA1 pyramidal neurons is mediated by protein kinase A. Proc Natl Acad Sci 106: 1620-1625.

Okamoto K, Bosch M, Hayashi Y. 2009. The roles of CaMKII and F-actin in the structural plasticity of dendritic spines: A potential molecular identity of a synaptic tag? Physiology (Bethesda) 24: 357-366.

Okuno H, Akashi K, Ishii Y, Yagishita-Kyo N, Suzuki K, Nonaka M, Kawashima T, Fujii H, Takemoto-Kimura S, Abe M, et al. 2012. Inverse synaptic tagging of inactive synapses via dynamic interaction of Arc/ Arg3.1 with CaMKIIß. Cell 149: 886-898.

Ota KT, Pierre VJ, Ploski JE, Queen K, Schafe GE. 2008. The NO-cGMP-PKG signaling pathway regulates synaptic plasticity and fear memory consolidation in the lateral amygdala via activation of ERK/MAP kinase. Learn Mem 15: 792-805.

Ota KT, Monsey MS, Wu MS, Schafe GE. 2010. Synaptic plasticity and NO-cGMP-PKG signaling regulate pre- and postsynaptic alterations at rat lateral amygdala synapses following fear conditioning. PLoS One 5: e11236.

Ou LC, Gean PW. 2006. Regulation of amygdala-dependent learning by brain-derived neurotrophic factor is mediated by extracellular signal-regulated kinase and phosphatidylinositol-3-kinase. Neuropsychopharmacology 31: 287-296.

Pal I, Mandal M. 2012. PI3K and Akt as molecular targets for cancer therapy: Current clinical outcomes. Acta Pharmacol Sin 33: 1441-1458.

Pan YW, Chan GC, Kuo CT, Storm DR, Xia Z. 2012. Inhibition of adult neurogenesis by inducible and targeted deletion of ERK5 mitogen-activated protein kinase specifically in adult neurogenic regions impairs contextual fear extinction and remote fear memory. I Neurosci 32: 6444-6455.

Papoutsi A, Sidiropoulou K, Poirazi P. 2012. Memory beyond synaptic plasticity: The role of intrinsic neuronal excitability. In Memory mechanisms in health and disease (ed. Giese KP), pp. 53-80. World Scientific Publishing, Singapore.

Park J, Leong ML, Buse P, Maiyar AC, Firestone GL, Hemmings BA. 1999. Serum and glucocorticoid-inducible kinase (SGK) is a target of the PI3-kinase-stimulated signaling pathway. EMBO J 18: 3024-3033.

Parsons RG, Gafford GM, Helmstetter FJ. 2006. Translational control via the mammalian target of rapamycin pathway is critical for the formation and stability of long-term fear memory in amygdala neurons. J Neurosci 26: 12977-12983.

Pastalkova E, Serrano P, Pinkhasova D, Wallace E, Fenton AA, Sacktor TC. 2006. Storage of spatial information by the maintenance mechanism of LTP. Science 313: 1141-1144.

Patrick GN, Zukerberg L, Nikolic M, de la Monte S, Dikkes P, Tsai LH. 1999. Conversion of p35 to p25 deregulates Cdk5 activity and promotes neurodegeneration. Nature 402: 615-622.

Paul C, Schoberl F, Weinmeister P, Micale V, Wotjak CT, Hofmann F, Kleppisch T. 2008. Signaling through cGMP-dependent protein kinase I in the amygdala is critical for auditory-cued fear memory and long-term potentiation. J Neurosci 28: 14202-14212.

Peineau S, Taghibiglou C, Bradley C, Wong TP, Liu L, Lu J, Lo E, Wu D, Saule E, Bouschet T, et al. 2007. LTP inhibits LTD in the hippocampus via regulation of GSK3 $\beta$. Neuron 53: 703-717.

Peters M, Mizuno K, Ris L, Angelo M, Godaux E, Giese KP. 2003. Loss of $\mathrm{Ca}^{2+} /$ calmodulin kinase kinase $\beta$ affects the formation of some, but not all, types of hippocampus-dependent long-term memory. J Neurosci 23: 9752-9760.

Philips GT, Tzvetkova EI, Carew TJ. 2007. Transient mitogen-activated protein kinase activation is confined to a narrow temporal window required for the induction of two-trial long-term memory in Aplysia. I Neurosci 27: 13701-13705.

Prybylowski K, Chang K, Sans N, Kan L, Vicini S, Wenthold RJ. 2005. The synaptic localization of NR2B-containing NMDA receptors is controlled by interactions with PDZ proteins and AP-2. Neuron 47: 845-857. 
Quevedo J, Vianna MR, Martins MR, Barichello T, Medina JH, Roesler R, Izquierdo I. 2004. Protein synthesis, PKA, and MAP kinase are differentially involved in short- and long-term memory in rats. Behav Brain Res 154: 339-343.

Radwanska K, Tudor-Jones AA, Mizuno K, Pereira GS, Lucchesi W, Alfano I, Lach A, Kaczmarek L, Knapp S, Giese KP. 2010. Differential regulation of CaMKII inhibitor $\beta$ protein expression after exposure to a novel context and during contextual fear memory formation. Genes Brain Behav 9: $648-657$.

Radwanska K, Medvedev NI, Pereira GS, Engmann O, Thiede N, Moraes MF, Villers A, Irvine EE, Maunganidze NS, Pyza EM, et al. 2011. Mechanism for long-term memory formation when synaptic strengthening is impaired. Proc Natl Acad Sci 108: 18471-18475.

Ravni A, Vaudry D, Gerdin MJ, Eiden MV, Falluel-Morel A, Gonzalez BJ, Vaudry H, Eiden LE. 2008. A cAMP-dependent, protein kinase A-independent signaling pathway mediating neuritogenesis through Egr1 in PC12 cells. Mol Pharmacol 73: 1688-1708.

Redondo RL, Okuno H, Spooner PA, Frenguelli BG, Bito H, Morris RG. 2010. Synaptic tagging and capture: Differential role of distinct calcium/ calmodulin kinases in protein synthesis-dependent long-term potentiation. J Neurosci 30: 4981-4989.

Reese LC, Laezza F, Woltjer R, Taglialatela G. 2011. Dysregulated phosphorylation of calcium/calmodulin-dependent protein kinase II- $\alpha$ in the hippocampus of subjects with mild cognitive impairment and Alzheimer's disease. J Neurochem 119: 791-804.

Ris L, Angelo M, Plattner F, Capron B, Errington ML, Bliss TV, Godaux E, Giese KP. 2005. Sexual dimorphisms in the effect of low-level p25 expression on synaptic plasticity and memory. Eur J Neurosci 21: $3023-3033$.

Rossato JI, Bevilaqua LR, Lima RH, Medina JH, Izquierdo I, Cammarota M. 2006. On the participation of hippocampal p38 mitogen-activated protein kinase in extinction and reacquisition of inhibitory avoidance memory. Neuroscience 143: 15-23.

Sacktor TC. 2011. How does PKM $\zeta$ maintain long-term memory? Nat Rev Neurosci 12: 9-15.

Sananbenesi F, Fischer A, Wang X, Schrick C, Neve R, Radulovic J, Tsai LH. 2007. A hippocampal Cdk5 pathway regulates extinction of contextual fear. Nat Neurosci 10: 1012-1019.

Sanhueza M, Lisman J. 2013. The CaMKII/NMDAR complex as a molecular memory. Mol Brain 6: 10.

Sanhueza M, Fernandez-Villalobos G, Stein IS, Kasumova G, Zhang P, Bayer KU, Otmakhov N, Hell JW, Lisman J. 2011. Role of the CaMKII/ NMDA receptor complex in the maintenance of synaptic strength. $J$ Neurosci 31: 9170-9178.

Schmitt JM, Guire ES, Saneyoshi T, Soderling TR. 2005. Calmodulindependent kinase kinase/calmodulin kinase I activity gates extracellular-regulated kinase-dependent long-term potentiation. $J$ Neurosci 25: 1281-1290.

Schneider A, Mehmood T, Pannetier S, Hanauer A. 2011. Altered ERK/ MAPK signaling in the hippocampus of the mrsk2_KO mouse model of Coffin-Lowry syndrome. J Neurochem 119: 447-459.

Serrano P, Friedman EL, Kenney J, Taubenfeld SM, Zimmerman JM, Hanna J, Alberini C, Kelley AE, Maren S, Rudy JW, et al. 2008. PKM $\zeta$ maintains spatial, instrumental, and classically conditioned long-term memories. PLoS Biol 6: 2698-2706.

Shalin SC, Zirrgiebel U, Honsa KJ, Julien JP, Miller FD, Kaplan DR, Sweatt JD. 2004. Neuronal MEK is important for normal fear conditioning in mice. J Neurosci Res 75: 760-770.

Shema R, Haramati S, Ron S, Hazvi S, Chen A, Sacktor TC, Dudai Y. 2011. Enhancement of consolidated long-term memory by overexpression of protein kinase $M \zeta$ in the neocortex. Science 331: 1207-1210.

Shen K, Meyer T. 1999. Dynamic control of CaMKII translocation and localization in hippocampal neurons by NMDA receptor stimulation. Science 284: 34036-34044.

Sherrin T, Blank T, Hippel C, Rayner M, Davis RJ, Todorovic C. 2010. Hippocampal c-Jun-N-terminal kinases serve as negative regulators of associative learning. J Neurosci 30: 13348-13361.

Sherrin T, Blank T, Todorovic C. 2011. c-Jun N-terminal kinases in memory and synaptic plasticity. Rev Neurosci 22: 403-410.

Silva AJ, Paylor R, Wehner JM, Tonegawa S. 1992a. Impaired spatial learning in $\alpha$-calcium-calmodulin kinase II mutant mice. Science 257: 206-211.

Silva AJ, Stevens CF, Tonegawa S, Wang Y. 1992b. Deficient hippocampal long-term potentiation in $\alpha$-calcium-calmodulin kinase II mutant mice. Science 257: 201-206.

Silva AJ, Kogan JH, Frankland PW, Kida S. 1998. CREB and memory. Annu Rev Neurosci 21: $127-148$.

Sindreu CB, Scheiner ZS, Storm DR. 2007. $\mathrm{Ca}^{2+}$-stimulated adenylyl cyclases regulate ERK-dependent activation of MSK1 during fear conditioning. Neuron 53: 79-89.

Srivastava T, Fortin DA, Nygaard S, Kaech S, Sonenberg N, Edelman AM, Soderling TR. 2012. Regulation of neuronal mRNA translation by CaM-kinase I phosphorylation of eIF4GII. J Neurosci 32: 5620-5630.
Stewart MG, Popov VI. 2012. Structural synaptic and dendritic spine plasticity in the hippocampus. In Memory mechanisms in health and disease (ed. Giese KP), pp. 19-52. World Scientific Publishing, Singapore.

Stoica L, Zhu PJ, Huang W, Zhou H, Kozma SC, Costa-Mattioli M. 2011. Selective pharmacogenetic inhibition of mammalian target of rapamycin complex I (mTORC1) blocks long-term synaptic plasticity and memory storage. Proc Natl Acad Sci 108: 3791-3796.

Stone SSD, Frankland PW. 2012. Adult hippocampal neurogenesis and memory. In Memory Mechanisms in Health and Disease (ed. Giese KP), pp. 81-146. World Scientific Publishing, Singapore.

Swulius MT, Waxham MN. 2008. $\mathrm{Ca}^{2+} /$ calmodulin-dependent protein kinases. Cell Mol Life Sci 65: 2637-2657.

Tai DJ, Su CC, Ma YL, Lee EH. 2009. SGK1 phosphorylation of IкB Kinase $\alpha$ and p300 up-regulates NF-kB activity and increases

$\mathrm{N}$-methyl-D-aspartate receptor NR2A and NR2B expression. J Biol Chem 284: $4073-4089$.

Takao K, Tanda K, Nakamura K, Kasahara J, Nakao K, Katsuki M, Nakanishi K, Yamasaki N, Toyama K, Adachi M, et al. 2010. Comprehensive behavioral analysis of calcium/calmodulin-dependent protein kinase IV knockout mice. PLoS One 5: e9460.

Tandon A, Yu H, Wang L, Rogaeva E, Sato C, Chishti MA, Kawarai T, Hasegawa H, Chen F, Davies P, et al. 2003. Brain levels of CDK5 activator p25 are not increased in Alzheimer's or other neurodegenerative diseases with neurofibrillary tangles. J Neurochem 86: $572-581$

Taniguchi S, Fujita Y, Hayashi S, Kakita A, Takahashi H, Murayama S, Saido TC, Hisanaga S, Iwatsubo T, Hasegawa M. 2001. Calpainmediated degradation of p35 to p25 in postmortem human and rat brains. FEBS Lett 489: 46-50.

Tinsley CJ, Narduzzo KE, Brown MW, Warburton EC. 2012. A role for the CAMKK pathway in visual object recognition memory. Hippocampus 22: $466-476$.

Tronson NC, Schrick C, Guzman YF, Huh KH, Srivastava DP, Penzes P, Guedea AL, Gao C, Radulovic J. 2009. Segregated populations of hippocampal principal CA1 neurons mediating conditioning and extinction of contextual fear. J Neurosci 29: 3387-3394.

Tsokas P, Hsieh C, Wallace EJC, Cottrell JE, Fenton AA, Messing RO, Sacktor TC. 2012. Conditional knockout of the PKC/PKM $\zeta$ gene in the adult mouse hippocampus prevents L-LTP. In 2012 Neuroscience meeting planner, abstract program no. 239.18. Society for Neuroscience, New Orleans, LA.

Valjent E, Corbille AG, Bertran-Gonzalez J, Herve D, Girault JA. 2006. Inhibition of ERK pathway or protein synthesis during reexposure to drugs of abuse erases previously learned place preference. Proc Natl Acad Sci 103: 2932-2937.

Valtcheva N, Nestorov P, Beck A, Russwurm M, Hillenbrand M, Weinmeister P, Feil R. 2009. The commonly used cGMP-dependent protein kinase type I (cGKI) inhibitor Rp-8-Br-PET-cGMPS can activate cGKI in vitro and in intact cells. J Biol Chem 284: 556-562.

van Woerden GM, Harris KD, Hojjati MR, Gustin RM, Qiu S, de Avila Freire R, Jiang YH, Elgersma Y, Weeber EJ. 2007. Rescue of neurological deficits in a mouse model for Angelman syndrome by reduction of $\alpha$ CaMKII inhibitory phosphorylation. Nat Neurosci 10: 280-282.

Volk LJ, Bachman JL, Johnson R, Yu Y, Huganir RL. 2013. PKM- $\zeta$ is not required for hippocampal synaptic plasticity, learning and memory. Nature 493: 420-423.

von Hertzen LS, Giese KP. 2005. Memory reconsolidation engages only a subset of immediate-early genes induced during consolidation. $J$ Neurosci 25: $1935-1942$.

Wayman GA, Lee YS, Tokumitsu H, Silva AJ, Soderling TR. 2008. Calmodulin-kinases: Modulators of neuronal development and plasticity. Neuron 59: 914-931.

Weeber EJ, Atkins CM, Selcher JC, Varga AW, Mirnikjoo B, Paylor R, Leitges M, Sweatt JD. 2000. A role for the $\beta$ isoform of protein kinase C in fear conditioning. J Neurosci 20: 5906-5914.

Wei F, Qiu CS, Liauw J, Robinson DA, Ho N, Chatila T, Zhuo M. 2002. Calcium calmodulin-dependent protein kinase IV is required for fear memory. Nat Neurosci 5: 573-579.

Westmark PR, Westmark CJ, Wang S, Levenson J, O'Riordan KJ, Burger C, Malter JS. 2010. Pin1 and PKM $\zeta$ sequentially control dendritic protein synthesis. Sci Signal 3: pra18.

Whitlock JR, Heynen AJ, Shuler MG, Bear MF. 2006. Learning induces long-term potentiation in the hippocampus. Science 313: 1093-1097.

Wu GY, Deisseroth K, Tsien RW. 2001. Activity-dependent CREB phosphorylation: Convergence of a fast, sensitive calmodulin kinase pathway and a slow, less sensitive mitogen-activated protein kinase pathway. Proc Natl Acad Sci 98: 2808-2813.

Wu P, Xue YX, Ding ZB, Xue LF, Xu CM, Lu L. 2011. Glycogen synthase kinase $3 \beta$ in the basolateral amygdala is critical for 
the reconsolidation of cocaine reward memory. J Neurochem 118: $113-125$.

Wu-Zhang AX, Schramm CL, Nabavi S, Malinow R, Newton AC. 2012. Cellular pharmacology of protein kinase $\mathrm{M} \zeta(\mathrm{PKM} \zeta)$ contrasts with its in vitro profile: Implications for PKM $\zeta$ as a mediator of memory. J Biol Chem 287: 12879-12885.

Xia Z, Storm DR. 2012. Role of signal transduction crosstalk between adenylyl cyclase and MAP kinase in hippocampus-dependent memory. Learn Mem 19: 369-374.

Yamagata Y, Kobayashi S, Umeda T, Inoue A, Sakagami H, Fukaya M, Watanabe M, Hatanaka N, Totsuka M, Yagi T, et al. 2009. Kinase-dead knock-in mouse reveals an essential role of kinase activity of $\mathrm{Ca}^{2+} /$ calmodulin-dependent protein kinase II $\alpha$ in dendritic spine enlargement, long-term potentiation, and learning. J Neurosci 29: 7607-7618.

Yamasaki N, Maekawa M, Kobayashi K, Kajii Y, Maeda J, Soma M, Takao K, Tanda K, Ohira K, Toyama K, et al. 2008. $\alpha$-CaMKII deficiency causes immature dentate gyrus, a novel candidate endophenotype of psychiatric disorders. Mol Brain 1: 6.
Yang Y, Liu D, Shang Y, Wu Y, Pei L, Xu X, Tian Q, Zhang J, Qian K, Wang YX, et al. 2012. EPAC null mutation impairs learning and social interactions via aberrant regulation of miR-124 and Zif268 translation. Neuron 73: 774-788.

Yao Y, Shao C, Jothianandan D, Tcherepanov A, Shouval H, Sacktor TC. 2012. Matching biochemical and functional efficacies confirm ZIP as a potent competitive inhibitor of PKM $\zeta$ in neurons. Neuropharmacology 64: 37-44.

Yoo BC, Lubec G. 2001. p25 protein in neurodegeneration. Nature 411: 763-764; discussion 764-765.

Young JZ, Isiegas C, Abel T, Nguyen PV. 2006. Metaplasticity of the late-phase of long-term potentiation: A critical role for protein kinase A in synaptic tagging. Eur J Neurosci 23: 1784-1794.

Zeng Y, Zhao D, Xie CW. 2010. Neurotrophins enhance CaMKII activity and rescue amyloid- $\beta$-induced deficits in hippocampal synaptic plasticity. J Alzheimer's Dis 21: 823-831.

Received March 14, 2013; accepted in revised form May 15, 2013. 


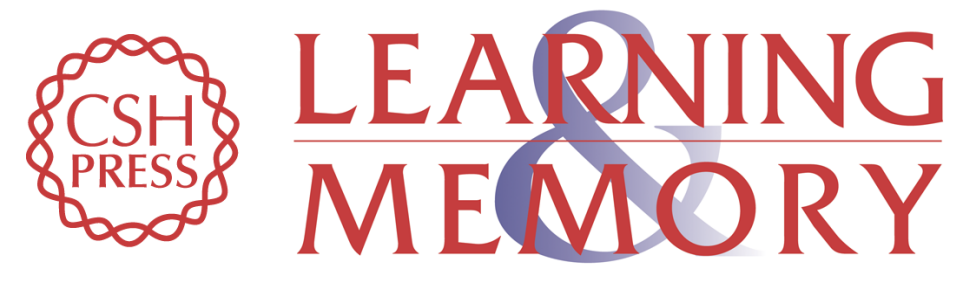

\section{The roles of protein kinases in learning and memory}

Karl Peter Giese and Keiko Mizuno

Learn. Mem. 2013, 20:

Access the most recent version at doi:10.1101//m.028449.112

References This article cites 203 articles, 65 of which can be accessed free at: http://learnmem.cshlp.org/content/20/10/540.full.html\#ref-list-1

Creative This article is distributed exclusively by Cold Spring Harbor Laboratory Press for the Commons first 12 months after the full-issue publication date (see

License http://learnmem.cshlp.org/site/misc/terms.xhtml). After 12 months, it is available under a Creative Commons License (Attribution-NonCommercial 3.0 Unported), as described at http://creativecommons.org/licenses/by-nc/3.0/.

Email Alerting Receive free email alerts when new articles cite this article - sign up in the box at the Service top right corner of the article or click here. 